[Frontiers in Bioscience S4, 1044-1064, January 1, 2012]

\title{
Differential roles of NADPH oxidases in vascular physiology and pathophysiology
}

\author{
Angelica M. Amanso ${ }^{1}$, Kathy K. Griendling ${ }^{1}$ \\ ${ }^{I}$ Department of Medicine, Division of Cardiology, Emory University, Division of Cardiology, 319 WMB, 1639 Pierce Dr, \\ Atlanta, GA 30322
}

\section{TABLE OF CONTENTS}

1. Abstract

2. Introduction

3. NADPH oxidases

4. Regulation of vascular tone

5. Vascular remodeling and extracellular matrix reorganization

6. Phenotypic modulation (proliferation and differentiation)

7. Migration

8. Apoptosis and senescence

9. Hypoxia

10. Pulmonary hypertension

11. Atherosclerosis

12. Angiogenesis

13. Diabetic vascular disease

14. Perspective

15. Acknowledgments

16. References

\section{ABSTRACT}

Reactive oxygen species (ROS) are produced by all vascular cells and regulate the major physiological functions of the vasculature. Production and removal of ROS are tightly controlled and occur in discrete subcellular locations, allowing for specific, compartmentalized signaling. Among the many sources of ROS in the vessel wall, NADPH oxidases are implicated in physiological functions such as control of vasomotor tone, regulation of extracellular matrix and phenotypic modulation of vascular smooth muscle cells. They are involved in the response to injury, whether as an oxygen sensor during hypoxia, as a regulator of protein processing, as an angiogenic stimulus, or as a mechanism of wound healing. These enzymes have also been linked to processes leading to disease development, including migration, proliferation, hypertrophy, apoptosis and autophagy. As a result, NADPH oxidases participate in atherogenesis, systemic and pulmonary hypertension and diabetic vascular disease. The role of ROS in each of these processes and diseases is complex, and a more full understanding of the sources, targets, cell-specific responses and counterbalancing mechanisms is critical for the rational development of future therapeutics.

\section{INTRODUCTION}

Virtually all resident cells in the vessel wall produce and respond to reactive oxygen species (ROS) (1-4). Vascular smooth muscle cells (VSMCs) in response to stimuli change phenotype from quiescent/contractile to synthetic, being able to proliferate, migrate and synthesize extracellular matrix. Endothelial cells respond to vasoactive agents by releasing nitric oxide (NO) to regulate vascular tone, by maintaining the pro/antithrombotic balance, and by promoting or inhibiting permeability and inflammation. Adventitial fibroblasts can influence vessel contraction and medial hypertrophy. ROS have been recognized as key regulators of many of these responses. More recently, it has been recognized that redox processes occur in a compartmentalized manner, with generation of different ROS in distinct organelles by several cellular enzyme systems (5-7). Vascular cells have diverse sources of ROS, namely from oxidative ATP generation in the mitochondria, xanthine oxidase during the metabolic pathway for acid uric formation, oxidoreductases such as cytochrome P450, glutathione peroxidase and myeloperoxidase, multiple thiol-disulfide exchanges during folding of nascent proteins in the endoplasmic reticulum, uncoupled nitric oxide synthases and Nox family NADPH 
Table 1. Nox enzymes in the vasculature

\begin{tabular}{|c|c|c|c|c|c|c|c|}
\hline $\begin{array}{l}\begin{array}{l}\text { Nox } \\
\text { member }\end{array} \\
\end{array}$ & localization & ROS type & Regulators & Expression & Activation & Cardiovascular physiology & $\begin{array}{l}\begin{array}{l}\text { Cardiovascular } \\
\text { pathophysiology }\end{array} \\
\end{array}$ \\
\hline \multicolumn{8}{|l|}{ Nox1 } \\
\hline & Transmenbrane & Superoxide & P22phox & Smooth muscle cells & Stimulus induced & Proliferation, migration & Vascular hypertrophy \\
\hline & Caveolae & Anion & $\begin{array}{l}\text { P47phox, } \\
\text { noxa1, rac }\end{array}$ & Epithelial cells, uterus & Ang ii, pdgf, fgf & $\begin{array}{l}\text { Extracellular matrix } \\
\text { production }\end{array}$ & $\begin{array}{l}\text { Hypertension, } \\
\text { vascular injury }\end{array}$ \\
\hline & Endosomes & & $\begin{array}{l}\text { Or noxol, } \\
\text { noxa1, rac }\end{array}$ & Osteoclasts, neurons & & Host defense & Diabetes \\
\hline \multicolumn{8}{|l|}{ Nox2 } \\
\hline & Phagosomes & Superoxide & $\begin{array}{l}\text { P22phox, } \\
\text { p47phox, }\end{array}$ & Endothelial cells & Agonist-induced & Angiogenesis & Hypoxia, diabetes \\
\hline & Caveolae & Anion & $\begin{array}{l}\text { P67phox, } \\
\text { p40phox }\end{array}$ & $\begin{array}{l}\text { Cardiomyocytes, } \\
\text { hepatocytes }\end{array}$ & $\begin{array}{l}\text { (ang ii, vegf, tnf } \alpha \text {, } \\
\text { endothelin1) }\end{array}$ & Apoptosis, oxygen sensing & Hypercholesterolemia \\
\hline & Endosomes & & Rac & Fibroblastes, phagocytes & Mechanical forces & Inflammation & $\begin{array}{l}\text { Pulmonary } \\
\text { hypertension }\end{array}$ \\
\hline & & & & $\begin{array}{l}\text { Neurons, skeletal muscle } \\
\text { myocytes }\end{array}$ & & & \\
\hline \multicolumn{8}{|l|}{ Nox3 } \\
\hline & $\begin{array}{l}\text { Plasma } \\
\text { membrane }\end{array}$ & Superoxide & $\begin{array}{l}\text { P22phox, } \\
\text { noxo1 }\end{array}$ & Inner ear & Agonist-induced $(\operatorname{tnf} \alpha)$ & & \\
\hline & & Anion & $\begin{array}{l}\text { Possibly } \\
\text { Noxa1, Rac } \\
\end{array}$ & Lung endothelial cells & Constitutively active & Unknown & $\begin{array}{l}\text { Insulin resistance } \\
\end{array}$ \\
\hline & & & & Hepatocytes & & & \\
\hline \multicolumn{8}{|l|}{ Nox4 } \\
\hline & Focal adhesion & Hydrogen & P22phox & $\begin{array}{l}\text { Mesangial cells, smooth } \\
\text { muscle }\end{array}$ & Constitutively active & Senescence, apoptosis & Hypertrophy \\
\hline & Nucleus & Peroxide & $\begin{array}{l}\text { Poldip2 } \\
\end{array}$ & $\begin{array}{l}\text { Endothelial cells, } \\
\text { fibroblasts }\end{array}$ & $\begin{array}{l}\text { Stimulus induced } \\
\end{array}$ & Endoplasmic reticulum stress & $\begin{array}{l}\text { Pulmonary } \\
\text { hypertension/fibrosis }\end{array}$ \\
\hline & $\begin{array}{l}\begin{array}{l}\text { Endoplasmic } \\
\text { reticulum }\end{array} \\
\end{array}$ & & & $\begin{array}{l}\text { Keratinocytes, } \\
\text { osteoclasts }\end{array}$ & (tgfß, il-1, vit.d, thrombin, & $\begin{array}{l}\text { Survival, differentiation } \\
\end{array}$ & Metabolic syndrome \\
\hline & & & & Neurons, hepatocytes & ER stressors) & Oxygen sensing & \\
\hline & & & & Cardiomyocytes & & Cytoskeletal regulation & \\
\hline \multicolumn{8}{|l|}{ Nox5 } \\
\hline & $\begin{array}{l}\text { Internal } \\
\text { membranes }\end{array}$ & Superoxide & Calcium & $\begin{array}{l}\text { Endothelial cells } \\
\end{array}$ & Calcium activated & Proliferation & Unknown \\
\hline & $\begin{array}{l}\begin{array}{l}\text { Plasma } \\
\text { membrane }\end{array} \\
\end{array}$ & Anion & & Smooth muscle cells & & Inflammation & \\
\hline
\end{tabular}

oxidases $(3,5,8-12)$. Maintaining the proper local balance of ROS production and removal is essential for normal physiology, with excess ROS potentially contributing to disease development (13). This review will focus on the role of ROS in both of these processes, with particular emphasis on NADPH oxidase-derived signaling.

\section{NADPH OXIDASES}

The Nox protein family is a major source of ROS in vascular cells $(8,14)$. The first member of this family to be described was gp91phox or Nox2, which generates large amounts of ROS in phagocytic cells, acting as an important component of innate immunity (15). In 1999, mox 1 or NOH-1 (now called Nox1), a homolog of gp91phox, was discovered and was identified as an enzymatic source of ROS in non-phagocyte cells $(16,17)$. Since then seven members of the Nox family have been identified (Nox1Nox5, Duox1 and Duox2) $(2,18)$. These isoforms differ from one another in their patterns of expression, subcellular localization, type of ROS produced and mode of activation (Table 1).

The Nox proteins generate ROS by transfer of a single electron from NADPH to molecular oxygen (18). The proteins have an oxidoreductase structure with a transmembrane region that contains two heme groups and a cytosolic portion with NADPH and FAD binding sites (8, 18-20). Nox1-4 require p22phox for their activity while Nox5 does not (20-22). p22phox is a regulatory membrane protein that functions as a docking site for regulatory proteins (p40phox, p47phox and p67phox for Nox2; Noxa1 and Noxo1 for Nox1 and 3; polymerase delta interacting protein 2 (Poldip2) for Nox4) $(2,10,23-27)$. The small
GTPase Rac also regulates Nox1-3 activity (8, 23, 28-30). Nox 5 also differs from the other Nox enzymes in that it does not require any cytosolic subunits (31). Structure predicts that all isoforms release superoxide $\left(\mathrm{O}_{2}{ }^{-}\right)$; however, while this is true for Nox1, Nox2, Nox3 and Nox5, Nox4 and the Duox enzymes release mostly hydrogen peroxide $\left(\mathrm{H}_{2} \mathrm{O}_{2}\right)(8,32)$. In vascular cells, Nox1, Nox2, Nox4 and Nox5 have been linked to several pathophysiological conditions such as hypertension, atherosclerosis, restenosis after injury and diabetic vasculopathy (32-36).

Nox1, found in plasma membrane, caveolae and endosomes in VSMCs, is induced by growth factors and vasoactive agents and activated by Src-dependent, protein kinase C (PKC)-mediated p47phox phosphorylation (18, $37,38)$. Nox 2 is present in plasma membrane and is activated similarly to vascular Nox1 $(14,39)$. Nox4 is thought to be constitutively activated and its activity is correlated with its level of expression (40). However, recent studies show that Nox 4 is regulated by Poldip 2 and such regulation increases its activity, although the mechanism remains to be determined (24). This novel partner colocalizes with p22phox and Nox4 at focal adhesions and in the nucleus of VSMCs (24). Nox4 is also found in the perinuclear space, endoplasmic reticulum and plasma membrane (37). Another potential regulatory mechanism for Nox4 (and Nox1) involves a chaperone of the endoplasmic reticulum, protein disulfide isomerase (PDI) (41). Downregulation of PDI decreases the Nox activity induced by angiotensin II (Ang II), which has previously been attributed to Nox1 (42). For Nox4, however, the relationship with PDI may be due to an interaction between oxidative and endoplasmic reticulum 
stress (43-45). Nox5 is regulated by elevation of calcium levels, and is found in the cytoskeletal fraction, endoplasmic reticulum and plasma membrane. Like Nox5, Duox enzymes are activated directly by calcium, although they do not appear to be expressed in the vasculature $(8,10$, $14,18,20,22,46)$.

\section{REGULATION OF VASCULAR TONE}

Nox-derived ROS have physiological and pathophysiological roles in the cardiovascular system. As noted, Nox enzymes promote cell growth, migration, proliferation and differentiation, and these effects have been related with pathophysiological conditions. However, Nox enzymes are not important only in cell injury conditions, but also during development, reparative processes and in the physiology of the vascular tone and oxygen sensing $(8,47)$.

The endothelial regulation of vascular tone is directly correlated with local production and activity of NO. This regulation is sensitive to any alterations in local stimuli such as shear stress or the presence of local vasodilators. In response to these stimuli, increases and redistribution of blood flow occur in specific vascular networks (48-50). The presence of $\mathrm{O}_{2}{ }^{--}$in this environment is an important foil to $\mathrm{NO}$ action, because $\mathrm{O}_{2}{ }^{--}$can rapidly interact with $\mathrm{NO}$ to form peroxynitrite $(51,52)$. Consequently, the bioavailability of NO is reduced and other reactive species are generated. Peroxynitrite can 1) uncouple endothelial nitric oxide synthase (eNOS) by oxidizing tetrahydrobiopterin $\left(\mathrm{BH}_{4}\right)$ thus leading to reduced $\mathrm{NO}$ and increased $\mathrm{O}_{2} ; 2$ ) inactivate prostacyclin synthase (an important source of endothelium-derived relaxing factor); and 3) inhibit superoxide dismutases, inducing oxidative stress $(53,54)$.

Conversely, it has been shown that $\mathrm{H}_{2} \mathrm{O}_{2}$ can induce and activate eNOS $(55,56) . \quad \mathrm{H}_{2} \mathrm{O}_{2}$ can also exert vasodilatory effects in vascular cells by hyperpolarization mechanisms (55-59). Recently, endothelial $\mathrm{H}_{2} \mathrm{O}_{2}$ has been proposed to be the endothelium-dependent hyperpolarization factor (EDHF) stimulated by shear stress to induce relaxation of the vessel $(60,61)$. Moreover, vascular overexpression of catalase counteracts the activity of some vasoconstrictor agents, suggesting that endogenous $\mathrm{H}_{2} \mathrm{O}_{2}$ may be an important regulator of blood pressure (62). On the other hand, other studies report that catalase has minimal effects on endothelium dependent relaxation in aorta and small arteries (63). Adventitia-derived $\mathrm{H}_{2} \mathrm{O}_{2}$ has been proposed to impair vascular relaxation via p38 mitogen-activated protein kinase (MAPK) activation and $\mathrm{SH}_{2}$ domain-containing protein tyrosine phosphatase-2 (SHP2) inhibition. Other findings implicate $\mathrm{H}_{2} \mathrm{O}_{2}$ dependent extracellular signal regulated kinase (ERK) $1 / 2$ activation in inhibiting relaxation $(58,64,65)$.

It is thus clear that ROS critically regulate vascular tone, but that their effects may be dependent upon the identity of ROS, the nature of the stimulus and the vascular bed upon which it acts. For example, $\mathrm{H}_{2} \mathrm{O}_{2}$ relaxes coronary and pulmonary arteries but may relax or constrict mesenteric arteries, while $\mathrm{O}_{2}{ }^{-}$inactivates $\mathrm{NO}$ to counteract relaxation and may directly constrict vessels (66). In human coronary arterioles, bradykinin-induced dilation is reduced by the Nox 2 inhibitor gp91ds-tat, suggesting that Nox2 mediates this response, but the relevant ROS is $\mathrm{H}_{2} \mathrm{O}_{2}$, which reduces the bioavailability of epoxyeicosatrienoic acids (67). Moreover, in this arterial bed, flow induces endothelial production of $\mathrm{H}_{2} \mathrm{O}_{2}$, which activates large conductance $\mathrm{Ca}^{2+}$-activated $\mathrm{K}^{+}$channels on the smooth muscle cells to induce relaxation (59). The multiple roles of ROS complicate the potential usefulness of Nox inhibitors in blood pressure regulation, since reduction of $\mathrm{O}_{2}^{--}$would favor improved relaxation and thus a lowering of blood pressure, but reduction of $\mathrm{H}_{2} \mathrm{O}_{2}$ might have the unwanted side effect of impairing coronary vasodilation. Because Nox $1 / 2$ generate $\mathrm{O}_{2}{ }^{-}$while Nox4 releases mostly $\mathrm{H}_{2} \mathrm{O}_{2}$, identifying which Nox is responsible for which response may allow us to specifically target the offending Nox in specific diseases.

\section{VASCULAR REMODELING AND EXTRACELLULAR MATRIX REORGANIZATION}

Vascular remodeling refers to a structural modification that results in changes in wall thickness and lumen diameter. Factors that may induce this response include passive adaptation to chronic hemodynamic stimuli, growth factors such as Ang II, and ROS. There are two kinds of remodeling: eutrophic or hypertrophic. In eutrophic remodeling the luminal diameter is reduced and the media becomes thicker with no overall change in crosssectional area. However, in the hypertrophic scenario wall cross-sectional area is increased, cell size is increased, and extracellular matrix (ECM) accumulation of proteins such as collagen and fibronectin is enhanced (68-71). This latter type of remodeling is present in hypertension (72).

Findings in the literature suggest an important role of Nox-derived ROS in hypertrophic remodeling. New Zealand obese mice with metabolic syndrome have increased vascular $\mathrm{O}_{2}^{--}$and peroxynitrite production, Nox activity and adhesion molecule expression, leading to hypertrophic vascular remodeling in mesenteric resistance arteries characterized by increased media:lumen ratio and media cross-sectional area $(73,74)$. Systemic administration of gp91phox-dstat, an inhibitor of Nox2, decreases Ang II-induced vascular hypertrophy (75). Nox1 has also been implicated in the oxidative, pressor, and hypertrophic responses to Ang II $(76,77)$.

Vascular remodeling also requires degradation and reorganization of the ECM proteins. The most important enzymes involved in these spatial dynamics are matrix metalloproteinases, a group of zinc-dependent endopeptidases that degrade ECM proteins such as fibronectin and collagen. High expression/activation of MMPs is a critical component of the vascular remodeling process $(78,79)$. Several studies indicate a role of Noxderived ROS in ECM turnover. ROS promote activation of MMP-2 and MMP-9 in VSMCs $(80,81)$. In addition, Ang II induces Nox-dependent expression of MMP-1, MMP-3 and MMP-9 (82). Mechanical stretch stimulates expression 
and release of MMP-2 by Nox-derived ROS (83). Moreover, the chloride-proton antiporter chloride channel-3 (ClC-3), which is required for endosome-dependent signaling by Nox 1 in VSMCs, contributes to neointimal hyperplasia after vascular injury by TNFalpha-mediated activation of MAPKs and MMP-9 (84-86). Similar effects of ROS on MMP-induced remodeling occur in other tissues as well, including TGFbeta-induced degradation of ECM and increased activity of MMP-9 during metastasis (71), TGFbeta-induced, Nox4-dependent fibrogenesis in lung injury (87), and TNFalpha-mediated, Nox-derived ROSdependent expression of MMP-9, but not MMP-2, in cardiomyocytes (88).

Lipopolysaccharide (LPS) induces ROS generation and increases the expression of Nox1 and Nox2, as well as the expression of several MMPs. Recent work showed that the regulation of MMPs and migration in macrophages stimulated with LPS is dependent on Nox2-, but not Nox1-derived ROS. While Nox1 small interfering RNA (siRNA) did not inhibit LPS-mediated expression of MMPs, Nox2 siRNA inhibited the expression of MMP-9, 10 and 12 (89).

\section{PHENOTYPIC MODULATION (PROLIFERATION AND DIFFERENTIATION)}

ROS including $\mathrm{O}_{2}^{--}$and $\mathrm{H}_{2} \mathrm{O}_{2}$ have important roles in the regulation of both proliferation and differentiation $(39,90)$. These mechanisms are crucial for not only the control of vasomotor tone, but also tissue repair and vascular remodeling. Low concentrations of $\mathrm{O}_{2}{ }^{-}$ and $\mathrm{H}_{2} \mathrm{O}_{2}$ induce proliferation, moderate concentrations induce either cell stasis or hypertrophy, and very high concentrations can induce apoptosis $(39,91-95)$. Thus, as with other cellular functions, the amount of ROS produced, their source and the subcellular compartment in which they are generated greatly influence the final response.

Differentiated VSMCs express contractile proteins such as smooth muscle $\alpha$-actin, calponin and smooth muscle myosin heavy chain, and have low proliferative capability and synthetic activity. In cardiovascular pathologies, VSMCs switch to the synthetic phenotype, proliferate and migrate, predisposing to vascular hypertrophy and lesion formation with elevated production of extracellular matrix (90). The mechanisms behind this phenotype switching are still very obscure; however, it is clear that physical and chemical changes in the environment modulate this process, namely humoral factors (platelet-derived growth factor (PDGF), TGFbeta, Ang II, endothelin-1 (ET-1)), neuronal signals, mechanical injury and changes in mechanical forces affecting cell-cell interaction and extracellular matrix (90). Nox1 and Nox4 appear to play very different roles during phenotypic modulation.

Nox4 is crucial for the maintenance of differentiation marker gene expression in VSMCs, stem cells, fibroblasts and pulmonary artery smooth muscle cells (14, 96-99). Low serum conditions or TGFbeta have been used as an external signal to induce differentiation in
VSMC. A recent study using TGFbeta suggests that Nox4 regulates smooth muscle alpha-actin gene expression via activation of p38MAPK and the serum-response factor (SRF)/myocardin-related transcription factor (MRTF) pathway in response to TGFbeta. Importantly, Nox4 has also been implicated in the differentiation of adipocytes, osteoblasts, chondrocytes and myofibroblasts. In adipocytes, Nox4 acts as a switch from insulin-induced proliferation to differentiation by controlling MAPK phosphatase-1 (MKP-1) expression, which controls ERK1/2 signaling (100). Similar to VSMCs, Nox4 mediates TGFbeta-stimulated fibroblast differentiation into a profibrotic, myofibroblast phenotype as well as the accompanying matrix production (101).

In contrast to the role of Nox4 in differentiation, Nox-mediated cell proliferation has been described in a several cell types present in blood vessels, kidney, liver, heart, lung epithelial cells and wide range of cancer cells $(39,102-105)$. In the blood vessel wall, ROS-mediated proliferation of VSMCs, adventitial fibroblasts and endothelial cells has been shown to be dependent on the Nox family proteins (105-107). Importantly, Nox isoforms seem to have different roles depending on their subcellular compartmentalization $(8,14)$.

Nox 1 is fundamentally important in cell proliferation in VSMCs. Nox1 is located in caveolae and downregulation of caveolin decreased ROS production as well cell proliferation in VSMCs treated with Ang II (37, $84,108,109)$. In addition, it has been implicated in the growth response to PDGF, thrombin and ET-1. Overexpression of Nox1 potentiates the effect of Ang II on vascular hypertrophy while downregulation inhibits it (103, 110-112). The importance of Nox 1 in proliferation has also been established in studies of neointima formation using genetically modified animal models (108), where injuryinduced neointima formation was reduced in Nox1 deficient animals and proliferation and migration were reduced in VSMCs cultured from these animals. Conversely, overexpression of the Nox 1 activator NoxA1 in mouse carotid arteries increased $\mathrm{O}_{2}^{-}$production in VSMCs and enhanced neointimal formation and atherosclerotic lesion formation (113). The mechanism appears to involve thrombin-induced activation of redoxsensitive mitogenic protein kinases that lead to proliferation.

The molecular mechanisms controlling Nox1mediated proliferation are only partially understood, but include activation of pro-growth signaling molecules such as kinases (p38MAPK and Akt), Ras and redox-sensitive transcriptional factors and inhibition of protein tyrosine phosphatases $(112,114)$. Only a few direct targets of ROS have been identified, and these are usually proteins with low pKa cysteine residues that can be oxidized by $\mathrm{H}_{2} \mathrm{O}_{2}$ $(115,116)$. Thus, antioxidant enzymes such as compartmentalized peroxiredoxins or thioredoxin are important regulators of the overall response (116).

Other recent findings underline the importance of cross-talk between redox pathways in Nox1-dependent 
proliferation. Manipulating the extracellular oxidationreduction state in aortic segments and VSMCs by altering the cysteine concentration (117) leads to an upregulation of Nox1 and an increase in proliferation. The mechanism appears to involve epidermal growth factor receptor phosphorylation by cleaved extracellular ligands following by ERK $1 / 2$ activation.

In endothelial cells, Nox 2 and Nox4 are the homologues that participate in cell proliferation. Their roles are not additive, but may be partially redundant (118120). Both EaHy926 endothelial cells (a cell line) and human microvascular endothelial cells utilize Nox2 and Nox4 equally for ROS production and proliferation. Depletion of Nox1 in these cells does not alter ROS levels under basal conditions (120). Another study showed that overexpression of Nox 4 enhanced receptor tyrosine kinase phosphorylation and the activation of ERK1/2, leading to enhanced proliferation and migration of endothelial cells (121).

\begin{abstract}
Nox2 has also been described as an important regulator of fibroblast proliferation since its downregulation results in reduction of serum-induced proliferation $(122,123)$. Others findings suggest that ROSderived from Nox family proteins in fibroblasts act as a paracrine stimulus on intimal cells and VSMCs to activate MAPKs and induce hypertrophy (124). Recently, it has been shown that Nox2 can regulate intracellular growth signaling pathways in adult hippocampal stem/progenitor cells, suggesting that, at least in the brain, ROS are important for maintaining specific cell populations and are not just related with deleterious conditions (125).
\end{abstract}

\section{MIGRATION}

Migration is a natural cellular process that is an integral part of vascular development as well as the healing response after vascular injury (126). ROS were first implicated in vascular migration more than 15 years ago when Sundarasen et al (104) showed that PDGF-induced VSMC migration was inhibited by catalase. Direct involvement of Nox-derived ROS in migration has also been shown for Ang II, ox-LDL, hypoxia, PDGF and vascular endothelial growth factor (VEGF) stimulation of either VSMCs or endothelial cells $(108,127-131)$. The signaling molecules so far identified as being regulated by ROS during migration are Src, RhoA, protein kinase C, phosphoinositide-3 (PI3) kinase, MAPKs including ERK1/2 and p38MAPK, NFkappaB, cofilin, slingshot-1 phosphatase (SSH1L) and Akt (126).

Several groups have described an interrelationship between PDGF and Nox1 or between basic fibroblast growth factor (bFGF) and Nox1 during migration $(108,127,128,132,133)$. Other work showed that heme oxygenase (HO-1) and carbon monoxide (CO) inhibit PDGF stimulated VSMC migration via inhibition of Nox1 activity (134). The mechanisms mediating the role of Nox1 in migration include the modulation of cytoskeletal rearrangement as well as regulation of matrix metalloproteinases. In terms of cytoskeletal dynamics,
PDGF regulates SSH1L phosphatase, an enzyme responsible for activation of cofilin and actin depolymerization, through Nox1-derived ROS (135). Similarly, bFGF activates c-Jun N-terminal kinase (JNK) via Nox1-dependent ROS production (136). Nox1 siRNA blocks the up-regulation of MMP-9 in K-Ras-transformed normal rat kidney cells. Downregulation of Nox1 inhibits the activation of inhibitor of NFkappaB kinase-alpha (IKKalpha) and the degradation of IkappaBalpha, thus suppressing the NFkappaB activity in the promoter of MMP-9 (137). In other models of migration, Nox1 knockdown inhibits the directional persistence of migration via Rho-dependent modulation of integrin expression (138).

Nox4 also appears to have an important function in migration (139). Knockdown of Nox4 inhibits insulinlike growth factor-1 (IGF-1)-induced migration at least in part due to suppression of MMP2 and MMP9 induction (139). PDGF-induced migration is inhibited by siRNA against Nox4 or its regulator Poldip 2 by a mechanism involving focal adhesion turnover (24). In a co-culture system of stromal mammary cells and epithelial cells, Nox4-dependent ROS production by TGFbeta stimulation of stromal cells mediates epithelial cell migration (140). Conversely, Nox4 overexpression has been shown to inhibit Ang II-induced myofibroblast migration via an $\mathrm{H}_{2} \mathrm{O}_{2}$ dependent pathway (141).

Normally, NO inhibits VSMC migration. However, in smooth muscle cells exposed to high glucose, NO loses its ability to inhibit migration due to glucoseinduced oxidation of the sarco/endoplasmic reticulum ATPase (SERCA) (142). Both Nox1 and Nox4 are upregulated in these conditions, and knockdown of either oxidase restores the inhibition of migration by NO. Blocking activation of Rac1 or p47phox has the same effect. Thus, it appears that the Nox family is the source of the oxidants responsible for the failure of NO to inhibit SMC migration in high glucose conditions (142). Similar results have been described in cultured aortic SMC from obese Zucker rats, a model of obesity and insulin resistance. Upregulation of Nox4 by TGFbeta via Smad2 promotes oxidation of SERCA and consequently impairs NO-mediated inhibition of serum-induced VSMC migration (143).

\section{APOPTOSIS AND AUTOPHAGY}

Cell survival/growth and cell death are cellular responses integral to all physiological processes. However, in many pathological conditions cell death induces tissue dysfunction leading to disease. Cells from renewable tissues have two mechanisms to avoid uncontrolled growth, namely cellular senescence, which consists of permanent cell cycle arrest, or initiation of cell death programs (apoptosis or autophagy). Apoptosis is defined as programmed cell death while autophagy represents a lysosomal degradation pathway of cytoplasmic components such as protein aggregates and damaged organelles. The primary function of autophagy is to maintain cellular homeostasis. Cells already terminally differentiated, such 
as neurons and cardiomyocytes, cannot become senescent $(144,145)$, but are subject to both apoptosis and autophagy.

ROS have been linked to cell death extensively in the literature. It is believed that temporally and spatially produced ROS regulate specific redox signaling pathways, while prolonged ROS generation in a diffuse manner can induce oxidative damage and consequently cell death $(146,147)$. Because Nox enzymes have specific subcellular localizations, they are likely to regulate the more specific death pathways. It is known, for example, that ROS regulate pro-apoptotic signaling (p38MAPK; JNK; apoptosis signal-regulating kinase (ASK1); $\mathrm{Ca}^{2+} /$ calmodulin-dependent protein kinase II (CaMKII); C/EBP-homologous protein (CHOP)) as well as anti-apoptotic pathways (Akt, ERK1/2, and heat shock proteins (HSPs)) (146).

Apoptosis is induced in vascular endothelial cells by homocysteine, TNFalpha and remnant lipoprotein particles (148-150). In addition, UV radiation promotes activation of Nox with consequent increased apoptosis in keratinocytes (151). Studies in the literature have implicated Nox2 in cardiomyocyte apoptosis induced by Ang II. In the presence of apocynin or in p47phox knockout mice apoptosis is abolished, suggesting the involvement of Nox2 (Nox1 and 3 are not detected in these cells) (152). Nox4 also appears to induce apoptosis in cultured cardiomyocytes as well mouse heart tissue. Nox4-induced apoptosis is accompanied by cytochrome-c release and is reversed by $\mathrm{Bcl}-\mathrm{xl}$ and manganese superoxide dismutase (MnSOD), suggesting involvement of the mitochondrial pathway. In addition, cardiac-specific Nox4 knockout mice have attenuated cardiomyocyte apoptosis $(153,154)$.

It is known that inactivation of the tumor suppressor p53 is strongly associated with pathological conditions in cardiovascular diseases. Overexpression of p53 promotes an increase in ROS in VSMCs with inhibition of proliferation and induction of apoptosis (102, 155-157), indicating that cell-cycle progression regulated by $\mathrm{p} 53$ in VSMCs is negatively regulated by ROS. Moreover, it has been described that VEGF-B is a potent negative regulator of apoptosis, potentially by inhibiting the expression of proapoptotic BH3-only proteins (members of the proapoptotic branch of the Bcl2 proteins) in mouse primary VSMCs (158).

Another mechanism leading to apoptosis is endoplasmic reticulum (ER) stress. This is a type of cellular dysfunction in which ER function, especially protein synthesis, is compromised, generating a specific signaling response called the Unfolded Protein Response (UPR) in order to restore homeostasis $(159,160)$. Transient ER stress is part of normal cellular physiology; however, chronic ER stress contributes to pathological conditions such as atherosclerosis, cardiac hypertrophy and the response to ischemia. If UPR fails to restore ER function, ER-initiated apoptotic signaling is induced (161-163).
In recent years, an important convergence between oxidative stress and ER stress has been recognized (164). Initially, it was thought that oxidative stress resulted from ER stress upon redox folding of nascent proteins where ROS generation occurs during thiol-disulfide exchanges involving ER oxidoreductases, including the flavooxidase Erol and PDI (165). However, a range of studies has correlated ER stress with Nox family proteins $(43,166-173)$. In human VSMCs, Nox4 mediates apoptosis induced by 7-ketocholesterol. The mechanisms involved are related with the apoptotic branch of ER stress signaling, namely the CHOP signaling pathway and activation of inositol-requiring enzyme-1 (IRE1), a proximal sensor for the status of ER luminal protein folding during the UPR (172). Moreover, a recent study showed that proteasome inhibition during UPR can directly affect Nox4 activity and impairs VSMC viability during ER stress induced by tunicamycin (166). Another important role of Nox4 in ER stress is related to its functional interaction with the phosphatase PTP1B in the ER. PTP1B is involved in the IRE-1 branch of UPR signaling during ER stress (174). Oxidation of PTP1B by ROS-derived from Nox4 reduces its activity (175). Finally, a recent study demonstrated that ischemia/reperfusion injury induces Nox4 expression in renal tubule cells. The authors showed an interaction between Toll-like receptor 4 , a $28 \mathrm{kDa}$ form of Nox4 and the ER resident protein gp96, a homologue of cytosolic Hsp90 that is involved in ROS production and TNF receptor-associated factor 2 (TRAF2)/ASK1/JNKmediated apoptosis in posthypoxic renal tubule cells. The authors suggested that Nox4 acts as a sensor in ER stressinduced proapoptotic signaling in this system (176).

Recent work showed that Nox2 also has an important role in oxidative and ER stress-induced apoptosis. Li et al (168) found that a branch of UPR signaling involving CHOP, EROlalpha and CAMKII induces Nox 2 and oxidative stress, which are necessary for ER stress induced apoptosis. In in vivo experiments, Nox2 deficiency protects against ER stress-induced renal cell apoptosis and CHOP activation as well renal dysfunction.

ER stress and autophagy are completely interrelated processes (163). It has been described that ER stress induces autophagy to protect against cell death (163). In addition, in the last few years data have been presented that relate NADPH oxidases and autophagy (177). Expression of GRP78, an ER chaperone and a required component of autophagy in mammalian cells (178), is prevented by Nox4 siRNA treatment during ER stress in human VSMCs (172). Moreover, Nox4-derived $\mathrm{H}_{2} \mathrm{O}_{2}$ has been shown to activate Ras/ERK in endothelial cells, leading to induction of autophagy, prevention cell death and enhanced differentiation (171). Some studies have also related Nox2 to Toll-like receptor-activated autophagy in phagocytes (179).

\section{HYPOXIA}

A primary function of blood vessels is to provide nutrients and $\mathrm{O}_{2}$ to maintain viability and physiological functions. Maintenance of oxygen homeostasis is crucial 
for development and evolution (180). Chronic hypoxia is considered to be a major mechanism involved in aging as well chronic diseases like pulmonary arterial hypertension $(\mathrm{PAH})$ and diabetes. During hypoxia (reduced $\mathrm{O}_{2}$ availability) adaptive mechanisms are induced in the vasculature. Hypoxia-inducible transcriptional (HIF) factors are induced that regulate genes involved in energy metabolism, angiogenesis and apoptosis $(181,182)$. One such factor, HIF-1alpha, is a major member of the HIF family and is normally degraded by the proteasome, but is stabilized in the presence of hypoxia (183). Interestingly, data in literature suggest that signaling induced by HIF is different among cell types. During development or regeneration processes, $\mathrm{O}_{2}$ is required due to cellular proliferation and hypertrophy. In such conditions $\mathrm{O}_{2}$ availability decreases and HIF-1 is activated. In response to tissue ischemia, vascular endothelial growth factor (VEGF), stem cell factor and PDGF are induced in a HIF1-dependent manner $(184,185)$. These factors then promote recovery after hypoxic injury, as shown in the impaired recovery of function after femoral artery ligation in heterozygous HIF-1alpha mice (185).

ROS have an important role in $\mathrm{O}_{2}$ homeostasis in many studies and Nox family proteins are suggested to be involved. Nox2 appears to be an $\mathrm{O}_{2}$ sensor in pulmonary airway chemoreceptors (186); however Nox2 is not required for the hypoxic pulmonary vasoconstriction response (187). Another study proposed that Nox1 is involved in induction of HIF-1, because Nox1-transfected cells show increased expression of HIF-1 that is inhibited by catalase and or DPI (188). In contrast, Nox4 is proposed to be a target of HIF-1 since overexpression of HIF-1 increases Nox4 expression and its downregulation prevents such an increase (189). Mutation of a putative hypoxiaresponsive element in the Nox4 promoter abolishes its induction by HIF-1. Nox4 has also been suggested to act as an oxygen sensor in conjunction with the TWIK-related acid-sensitive K+ channel TASK-1 $(190,191)$.

\section{PULMONARY HYPERTENSION}

Chronic PAH is an important clinical condition present in wide range of cardiovascular patients. The development of pulmonary hypertension is characterized by chronic hypoxia, endothelial injury and subsequent inflammation (192). The pulmonary circulation responds to local airway hypoxia with vasoconstriction in order to direct blood flow to better-ventilated regions of the lung. However, chronic hypoxia causes vascular remodeling associated with a loss of relaxation to endogenous $\mathrm{NO}$, increased levels of $\mathrm{O}_{2}{ }^{-}$and consequently increased pulmonary arterial pressure (193). As expected, ROS are involved in acute hypoxic vasoconstriction in the lung, as demonstrated by attenuation of vasoconstriction in the presence of SOD (194). Overexpression of extracellular SOD also attenuates vascular remodeling in chronic hypoxia (195).

In terms of the source of ROS involved in this response, many investigators have reported a role for NADPH oxidases. For example, Nox1 is upregulated in pulmonary resistance arteries of newborn piglets exposed to long-term hypoxia (196). Nox2-deficient mice show impairment of the vasoconstrictor response to ET-1 in the pulmonary vasculature after exposure to chronic hypoxia (197). Moreover, p47phox-deficient mice exhibit a reduction of acute hypoxic pulmonary vasoconstriction, while non-hypoxia-induced vasoconstrictions are not affected (198). Disruption of the Nox2 gene also has chronic effects: it inhibits hypoxia-induced PAH and vascular remodeling $(199,200)$. A number of other studies, however, suggest that it is Nox4 that has an important role in the vascular remodeling process. Nox 4 expression, but not that of the other Nox proteins, is upregulated in pulmonary artery smooth muscle cells (PASMC) of mice subjected to hypoxic conditions (201). This upregulation occurs via autocrine production of TGFbeta and insulinlike growth factor binding protein-3, and is necessary for PASMC proliferation (98). Another study found that downregulation of Nox4, but not of Nox2, promotes attenuation of hypoxic pulmonary vasoconstriction in bovine pulmonary arteries (202). The mechanisms by which hypoxia induces Nox4 and by which Nox4 influences vasoconstriction and remodeling are somewhat unclear, but likely involve the HIF family proteins and proliferator-activated receptor-gamma (PPARgamma). ROS-derived from Nox4 increase the activity of HIF-1 (203) and HIF-2alpha in PASMC (204). Diebold et al (189) found that hypoxia rapidly increases Nox4 mRNA and protein levels in PASMC as well as pulmonary vessels from mice in a HIF-1 dependent manner. PPARgamma appears to regulate hypoxia-stimulated Nox4 induction through an NFkappaB-mediated mechanism in human PASMC (205). It is clear that the contribution of NADPH oxidases to pulmonary hypertension is complex, and that more work is needed to fully understand the mechanisms involved.

\section{ATHEROSCLEROSIS}

Atherosclerosis is a long-term inflammatory disease considered to be a public health issue worldwide. The disease consists of formation of atherosclerotic plaques in hemodynamically unstable regions of the vessel. Risk factors associated with disease development and progression are diverse, but include genetic propensity, obesity, hypertension, hypercholesterolemia, diabetes and smoking. Many of the steps of the progression of disease are ROS-sensitive. Plaque development depends on the subendothelial retention of lipids; cytokines that induce inflammatory responses including endothelial activation and recruitment of immune cells (macrophages, dendritic cells, neutrophils, $\mathrm{B}$ and $\mathrm{T}$ cells); cell proliferation, migration, and secretion of extracellular matrix proteins; and cell death and activation of coagulation factors (206). All these processes have all been associated with activation of Nox family proteins.

Early in disease development, macrophages and other cells of the immune system that are rich in Nox2 invade the vessel wall, and induction and activation of other Nox proteins occur in resident vascular cells (39). ROS-derived from Nox enzymes contribute to macrophage- 
mediated oxidation of LDL, which can then activate Nox proteins in vascular cells, resulting in expression of adhesion molecules and the recruitment of immune cells $(207,208)$. It has been shown that $\mathrm{p} 47 \mathrm{phox}$ is required for atherosclerotic plaque evolution in ApoE transgenic mice $(209,210)$. Other data also support a role for Nox family proteins in atherosclerosis, such as the observation that Nox 1 mRNA and Nox4 mRNA in nonphagocytic cells, as well as expression of p22phox in phagocytes, are increased in atherosclerotic human coronary arteries $(39,130,211$, 212). In addition, recent work showed that knockout of Nox1 in mice lacking the ApoE gene also reduces lesion formation (211).

In the last few years, the relevance of ER stress and autophagy to the progression of atherosclerotic plaques has begun to be appreciated (213-215). Human atherosclerotic plaques show increased ER stress as assessed by expression of GRP78 and the pro-apoptotic factor CHOP. In the same study, the authors found 7-Ketocholesterol (cited above as an inducer of Nox4) in the fibrous caps of atherosclerotic plaques. Treatment of cultured coronary artery smooth muscle cells with 7- Ketocholesterol induced the upregulation of chaperones and apoptosis, and this effect was abolished by antioxidants (172). Apoptosis of macrophages regulated by $\mathrm{CHOP}$, and as a consequence an increase of the instability atherosclerotic plaques, has also been described by different groups $(172,216)$. More specifically, Thorp et al (217) tested the effect of CHOP deficiency in vivo by measuring aortic root lesions of fat-fed $\mathrm{Chop}^{+/+} \mathrm{ApoE}^{-/-}$and $\mathrm{Chop}^{-/} \mathrm{ApoE}^{-/-}$mice. They found that plaque necrosis was reduced by approximately $50 \%$ and lesional apoptosis by $35 \%$ in the CHOP-deficient mice.

As part of the evolution of atherosclerosis, chronic inflammatory processes become associated with Toll-like receptors (TLRs), regulators of innate immunity (218). It has been demonstrated that TLRs can promote activation of Nox proteins. Stimulation of TLR4 with LPS induces ROS generation and NFkappaB activation in HEK293 cells via a mechanism involving Nox4 (219). Nox4-dependent ROS generation is also important for generation of proinflamatory cytokines by LPS in endothelial cells (220). Recently, palmitate was proposed to induce inflammation in human endothelial cells. Like LPS, palmitate increases $\mathrm{O}_{2}^{--}$production and stimulates NFkappaB signaling via TLR4-mediated activation of Nox4 (221). Finally, high-fat feeding increases expression of Nox4 and bone morphogenic protein (BMP4) in thoracic aorta in wild type, but not TLR4 ${ }^{-/-}$mice $(221)$.

\section{ANGIOGENESIS}

Angiogenesis consists of the formation of new capillaries from preexisting vessels and is part of the process of neovascularization. During angiogenesis, endothelial cells proliferate, migrate and form capillary tubes. As described above, ROS play a crucial role in all of these processes. Importantly, Nox family proteins are activated by angiogenic stimuli such as VEGF, Ang II, hypoxia, cytokines and shear stress $(34,222)$. Transgenic mice overexpressing p22phox have increased VEGF expression and enhanced angiogenesis in experimental atheromas (223). Rac-1 mediated $\mathrm{O}_{2}^{--}$production mediates VEGF-induced placental angiogenesis (224) as well as that induced by overexpression of phosphodiesterase-2 (225). More specifically, a wide range of studies suggests a role for Nox2 in angiogenesis $(226,227)$. Studies using the hindlimb ischemia model in mice showed that Nox2 expression and ROS production are increased in bone marrow mononuclear cells (228). However, mice lacking Nox2 have impaired ischemia-induced blood flow recovery and neovascularization, which is associated with reduction of ROS production in bone marrow-derived cells as well as with a decrease in the number of endothelial progenitor cells in peripheral blood (228). Another study exposed p47phox deficient mice to arsenite in the drinking water. Environmental arsenic is a risk factor for developing vascular disease marked by pathologic remodeling. p47phox deficient mice were protected from arsenite-induced capillarization. Ex vivo arsenic exposure of endothelial cells led to increased $\mathrm{O}_{2}^{--}$generation that was inhibited by downregulation of Nox2, suggesting that Nox2 is required for capillarization (229).

Nox2 is not the only Nox involved, however: Nox1 overexpression can induce expression of VEGF and its receptors and upregulate matrix metalloproteinase activity through ROS generation, thus promoting angiogenesis (230). Nox1 downregulation decreases endothelial migration and tube-like structure formation by a mechanism involving NFkappaB signaling (137). Notably, mice deficient in Nox1, but not Nox4, exhibit impaired tumor angiogenesis (231). The role of Nox4 may be context dependent, however. Nox4-null animals exposed to chronic pressure overload develop contractile dysfunction, hypertrophy, and cardiac dilatation, whereas Nox4-trangenic mice are protected. The mechanism appears to be related to Nox4-dependent preservation of myocardial capillary density after pressure overload. Overexpression of Nox 5 induces endothelial proliferation and formation of capillary-like structures (22).

Alternatively, excess ROS production can impair angiogenesis. An example of this involves the effects of Ang II in formation of new vessels after ischemia. Ang II signaling has different effects on angiogenesis depending on the basal vascular oxidative stress. Elevated levels of basal ROS make the effect of Ang II on collateral growth inhibitory, while Ang II administered when basal levels of ROS are low promotes collateral growth (232). Another case where excess ROS have been shown to be inhibitory is in pulmonary artery endothelial cells from fetal lambs with persistent pulmonary hypertension. These cells have increased expression of Nox subunits (Nox4, Nox2, Rac1, p47phox and p67phox) and increased Nox activity, but exhibit decreased tube formation, cell proliferation, scratch recovery and cell invasion, suggesting that increased oxidative stress from Nox activity contributes to impaired angiogenesis in this model (233).

\section{DIABETIC VASCULAR DISEASE}

Diabetes mellitus is accompanied by an increased risk of developing cardiovascular disease. A wide range of 


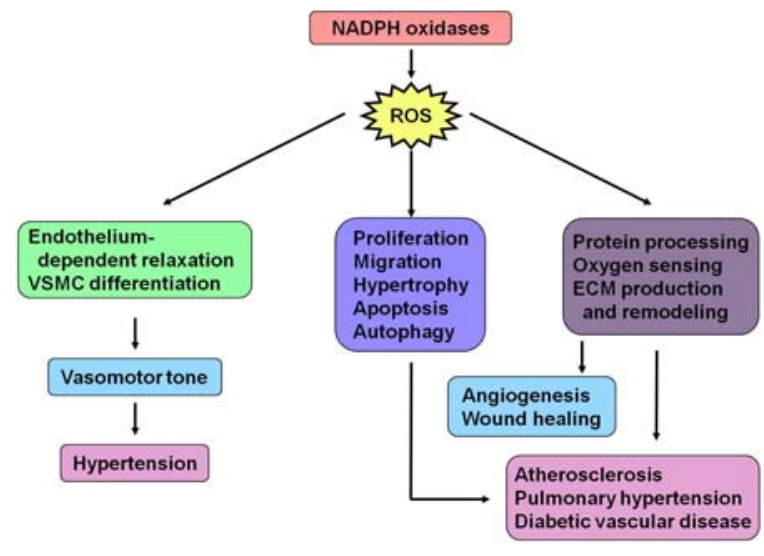

Figure 1. Diverse roles of NADPH oxidases in vascular physiology and pathophysiology. ROS generation by Nox enzymes maintain vascular tone and integrity, participate in the response to injury, and contribute to vascular diseases.

studies has implicated oxidative stress in the pathology of diabetes. Elevated oxidative stress is detected in diabetic patients and in animal models of diabetes (obese ob/ob mice, Zucker fatty rats, streptozotocin-induced diabetes) (234).

Hyperglycemia, hyperinsulinemia, and increased levels of lipids promote ROS generation in diverse cell types. The enzymatic sources of ROS include Nox family proteins, mitochondria and uncoupled NO synthases, with a very strong probability of cross-talk between them. Enhanced expression of p22phox, increased Nox activity and elevated $\mathrm{O}_{2}{ }^{-}$ production were found in mouse microvascular endothelial cells exposed to high glucose (235). High glucose, advanced glycation endproducts and free fatty acids induce expression and activity of Nox in VSMCs as well (236-239). In one study, downregulation of p47phox in VSMCs decreased $\mathrm{O}_{2}$ generation (235), and no apparent role for eNOS, mitochondria or xanthine oxidase was found (240). In contrast, another group showed that ROS generation by hyperglycemia was decreased by an inhibitor of electron transport chain complex II, uncoupling protein-1 or MnSOD in aortic endothelial cells (241). In aortas of streptozotocin diabetic rats, uncoupled eNOS and Nox2 have been implicated in ROS generation (242). It is thus clear that there are multiple sources of ROS in the diabetic vasculature, depending on cell type, stimulus and diabetic model.

PKC appears to be extremely important in Nox regulation and activation in diabetes. For example, activation of Nox was abolished in diabetic PKCbeta knockout mice (243). Other isoforms of PKC have been implicated as well: PKCalpha mediates Nox activation in the kidney of diabetic rats, PKCdelta in adipocytes (244) and PKCzeta in mesangial cells treated with high glucose (245). JNK activation and Akt inhibition may be downstream of Nox2-derived ROS, at least in beta-cells exposed to high glucose (246).

Insulin increases ROS generation in VSMCs, adipocytes, fibroblasts and macrophages (247-250). In macrophages, ROS induced by insulin are derived from Nox2
(250). In other insulin-sensitive cells, Nox4 appears to have important role in the response to insulin since its downregulation prevents ROS production and inactivation of phosphatase PTP1B, a widely expressed phosphatase implicated in the negative regulation of insulin signaling (251). Another study suggests that the upregulation of Nox4 by TGFbeta in VSMCs from obese Zucker rats is responsible for the impaired response to $\mathrm{NO}$ by a mechanism involving the oxidation of SERCA C674. Such mechanisms could explain the enhanced VSMC migration and neointima formation in type 2 diabetes (252).

Another effect of excess ROS generation in diabetes is impairment of acetylcholine-induced endothelium-dependent relaxation, a response that has been attributed to NADPH oxidases, at least in OLETF rats (253). Downregulation of Nox enzymes has also been shown to decrease the proinflammatory effects of AGEs in different cell types. For example, macrophages from $\mathrm{Nox}^{-/-}$mice showed inhibition of AGE effects (254). Downregulation of Nox1 impairs AGE-induced ROS production and induction of iNOS in VSMCS (237). Finally, treatment of $\mathrm{db} / \mathrm{db}$ mice (a model of type 2 diabetes) with the $\mathrm{O}_{2}{ }^{-}$scavenger tempol reduces expression of inflammatory genes in the vessel wall (236).

Pathways that inhibit Nox-dependent ROS production in diabetes are thus quite promising therapeutic targets for diabetic vascular dysfunction. One mechanism that reduces the enhanced PDGFinduced ROS generation that occurs in response to high glucose in VSMC is activation of the protein tyrosine phosphatase PTPepsilonM. PTPepsilonM negatively regulates PDGFbeta-receptor signaling, DNA synthesis and migration by reducing the phosphorylation level of the PDGFbeta receptor with subsequent downregulation of Nox1 and suppression of $\mathrm{H}_{2} \mathrm{O}_{2}$ generation (255). Another inhibitor of diabetes-induced oxidative stress is resveratrol. Resveratrol is a natural phytophenol found in wine that exhibits cardioprotective effects. It has been shown to reduce oxidative/nitrative stress and improve NO availability by inhibition of TNFalpha-induced NF-kappaB activation and expression and activation of Nox 2 and iNOS in type 2 diabetes (256).

\section{PERSPECTIVE}

Studies summarized in this review make it clear that Nox-derived ROS play a role in virtually all aspects of vascular function, both physiologically and pathophysiologically (Figure 1). Individual Nox enzymes play distinct roles both within a cell and between cell types. Moreover, Nox proteins exhibit considerable cross-talk with other oxidant-generating systems (33). As we begin to understand this differential regulation of ROS-dependent signaling, we will be able to more rationally develop therapies targeted to specific sources of ROS, rather than relying on global antioxidant treatments that have been suboptimal in the past. The complexities of redox regulation of vascular function provide fertile ground for future investigation. 


\section{ACKNOWLEDGMENTS}

This work was supported by NIH grants HL38206, HL092120, HL095070 and HL058863; and AHA 09POST2070000.

\section{REFERENCES}

1. D'Autreaux, B. and Toledano, M.B. ROS as signalling molecules: mechanisms that generate specificity in ROS homeostasis. Nat Rev Mol Cell Biol. 8 (10) 813-24 (2007)

2. Lambeth, J.D. Nox enzymes, ROS, and chronic disease: an example of antagonistic pleiotropy. Free Radic Biol Med. 43 (3) 332-47 (2007)

3. Mueller, C.F., Laude, K., McNally, J.S., and Harrison, D.G. ATVB in focus: redox mechanisms in blood vessels. Arterioscler Thromb Vasc Biol. 25 (2) 274-8 (2005)

4. Forstermann, U. Oxidative stress in vascular disease: causes, defense mechanisms and potential therapies. Nat Clin Pract Cardiovasc Med. 5 (6) 338-49 (2008)

5. Go, Y.M. and Jones, D.P. Cysteine/cystine redox signaling in cardiovascular disease. Free Radic Biol Med. 50 (4) 495-509 (2011)

6. Go, Y.M. and Jones, D.P. Redox control systems in the nucleus: mechanisms and functions. Antioxid Redox Signal. 13 (4) 489-509 (2010)

7. Go, Y.M. and Jones, D.P. Redox compartmentalization in eukaryotic cells. Biochim Biophys Acta. 1780 (11) 1273-90 (2008)

8. Lassegue, B. and Griendling, K.K. NADPH oxidases: functions and pathologies in the vasculature. Arterioscler Thromb Vasc Biol. 30 (4) 653-61 (2010)

9. Lyle, A.N. and Griendling, K.K. Modulation of vascular smooth muscle signaling by reactive oxygen species. Physiology (Bethesda). 21 269-80 (2006)

10. Brandes, R.P. and Schroder, K. Composition and functions of vascular nicotinamide adenine dinucleotide phosphate oxidases. Trends Cardiovasc Med. 18 (1) 15-9 (2008)

11. Gorlach, A., Klappa, P., and Kietzmann, T. The endoplasmic reticulum: folding, calcium homeostasis, signaling, and redox control. Antioxid Redox Signal. 8 (9-10) 1391-418 (2006)

12. Taylor, C.T. and Moncada, S. Nitric oxide, cytochrome C oxidase, and the cellular response to hypoxia. Arterioscler Thromb Vasc Biol. 30 (4) 643-7 (2010)

13. Jones, D.P. Redefining oxidative stress. Antioxid Redox Signal. 8 (9-10) 1865-79 (2006)
14. Brown, D.I. and Griendling, K.K. Nox proteins in signal transduction. Free Radic Biol Med. 47 (9) 1239-53 (2009)

15. Babior, B.M., Lambeth, J.D., and Nauseef, W. The neutrophil NADPH oxidase. Arch Biochem Biophys. 397 (2) 342-4 (2002)

16. Suh, Y.A., Arnold, R.S., Lassegue, B., Shi, J., Xu, X., Sorescu, D., Chung, A.B., Griendling, K.K., and Lambeth, J.D. Cell transformation by the superoxide-generating oxidase Mox1. Nature. 401 (6748) 79-82 (1999)

17. Banfi, B., Maturana, A., Jaconi, S., Arnaudeau, S., Laforge, T., Sinha, B., Ligeti, E., Demaurex, N., and Krause, K.H. A mammalian $\mathrm{H}+$ channel generated through alternative splicing of the NADPH oxidase homolog NOH1. Science. 287 (5450) 138-42 (2000)

18. Lambeth, J.D., Kawahara, T., and Diebold, B. Regulation of Nox and Duox enzymatic activity and expression. Free Radic Biol Med. 43 (3) 319-31 (2007)

19. Kawahara, T., Quinn, M.T., and Lambeth, J.D. Molecular evolution of the reactive oxygen-generating NADPH oxidase (Nox/Duox) family of enzymes. BMC Evol Biol. 7109 (2007)

20. Cheng, G., Cao, Z., Xu, X., van Meir, E.G., and Lambeth, J.D. Homologs of gp91phox: cloning and tissue expression of Nox3, Nox4, and Nox5. Gene. 269 (1-2) 131 40 (2001)

21. Banfi, B., Molnar, G., Maturana, A., Steger, K., Hegedus, B., Demaurex, N., and Krause, K.H. A Ca (2+)activated NADPH oxidase in testis, spleen, and lymph nodes. J Biol Chem. 276 (40) 37594-601 (2001)

22. BelAiba, R.S., Djordjevic, T., Petry, A., Diemer, K., Bonello, S., Banfi, B., Hess, J., Pogrebniak, A., Bickel, C., and Gorlach, A. NOX5 variants are functionally active in endothelial cells. Free Radic Biol Med. 42 (4) 446-59 (2007)

23. Geiszt, M., Lekstrom, K., Witta, J., and Leto, T.L. Proteins homologous to p47phox and p67phox support superoxide production by NAD (P)H oxidase 1 in colon epithelial cells. J Biol Chem. 278 (22) 20006-12 (2003)

24. Lyle, A.N., Deshpande, N.N., Taniyama, Y., SeidelRogol, B., Pounkova, L., Du, P., Papaharalambus, C., Lassegue, B., and Griendling, K.K. Poldip2, a novel regulator of Nox4 and cytoskeletal integrity in vascular smooth muscle cells. Circ Res. 105 (3) 249-59 (2009)

25. Banfi, B., Clark, R.A., Steger, K., and Krause, K.H. Two novel proteins activate superoxide generation by the NADPH oxidase NOX1. J Biol Chem. 278 (6) 3510-3 (2003)

26. Takeya, R., Ueno, N., Kami, K., Taura, M., Kohjima, M., Izaki, T., Nunoi, H., and Sumimoto, H. Novel human 
homologues of p47phox and p67phox participate in activation of superoxide-producing NADPH oxidases. $J$ Biol Chem. 278 (27) 25234-46 (2003)

27. Ueyama, T., Lekstrom, K., Tsujibe, S., Saito, N., and Leto, T.L. Subcellular localization and function of alternatively spliced Noxol isoforms. Free Radic Biol Med. 42 (2) 180-90 (2007)

28. Viedt, C., Fei, J., Krieger-Brauer, H.I., Brandes, R.P., Teupser, D., Kamimura, M., Katus, H.A., and Kreuzer, J. Role of p22phox in angiotensin II and platelet-derived growth factor AA induced activator protein 1 activation in vascular smooth muscle cells. J Mol Med. 82 (1) 31-8 (2004)

29. Ambasta, R.K., Kumar, P., Griendling, K.K., Schmidt, H.H., Busse, R., and Brandes, R.P. Direct interaction of the novel Nox proteins with p22phox is required for the formation of a functionally active NADPH oxidase. J Biol Chem. 279 (44) 45935-41 (2004)

30. Hanna, I.R., Hilenski, L.L., Dikalova, A., Taniyama, Y., Dikalov, S., Lyle, A., Quinn, M.T., Lassegue, B., and Griendling, K.K. Functional association of nox 1 with p22phox in vascular smooth muscle cells. Free Radic Biol Med. 37 (10) 1542-9 (2004)

31. Nauseef, W.M. Biological roles for the NOX family NADPH oxidases. J Biol Chem. 283 (25) 16961-5 (2008)

32. Brandes, R.P., Weissmann, N., and Schroder, K. NADPH oxidases in cardiovascular disease. Free Radic Biol Med. 49 (5) 687-706 (2010)

33. Datla, S.R. and Griendling, K.K. Reactive oxygen species, NADPH oxidases, and hypertension. Hypertension. 56 (3) 325-30 (2010)

34. Guzik, T.J. and Griendling, K.K. NADPH oxidases: molecular understanding finally reaching the clinical level? Antioxid Redox Signal. 11 (10) 2365-70 (2009)

35. Williams, H.C. and Griendling, K.K. NADPH oxidase inhibitors: new antihypertensive agents? $J$ Cardiovasc Pharmacol. 50 (1) 9-16 (2007)

36. Brandes, R.P. Out of balance: a role of impaired superoxide dismutase activity for vascular constrictive remodeling after angioplasty. Arterioscler Thromb Vasc Biol. 23 (12) 2121-2 (2003)

37. Hilenski, L.L., Clempus, R.E., Quinn, M.T., Lambeth, J.D., and Griendling, K.K. Distinct subcellular localizations of Nox1 and Nox4 in vascular smooth muscle cells. Arterioscler Thromb Vasc Biol. 24 (4) 677 83 (2004)

38. Helmcke, I., Heumuller, S., Tikkanen, R., Schroder, K., and Brandes, R.P. Identification of structural elements in Nox1 and Nox4 controlling localization and activity. Antioxid Redox Signal. 11 (6) 1279-87 (2009)
39. Lassegue, B. and Griendling, K.K. NADPH oxidases: functions and pathologies in the vasculature. Arterioscler Thromb Vasc Biol. 30 (4) 653-61 (2010)

40. Serrander, L., Cartier, L., Bedard, K., Banfi, B., Lardy, B., Plastre, O., Sienkiewicz, A., Forro, L., Schlegel, W., and Krause, K.H. NOX4 activity is determined by mRNA levels and reveals a unique pattern of ROS generation. Biochem J. 406 (1) 105-14 (2007)

41. Janiszewski, M., Lopes, L.R., Carmo, A.O., Pedro, M.A., Brandes, R.P., Santos, C.X., and Laurindo, F.R. Regulation of NAD (P)H oxidase by associated protein disulfide isomerase in vascular smooth muscle cells. $J$ Biol Chem. 280 (49) 40813-9 (2005)

42. Lassegue, B., Sorescu, D., Szocs, K., Yin, Q., Akers, M., Zhang, Y., Grant, S.L., Lambeth, J.D., and Griendling, K.K. Novel gp91 (phox) homologues in vascular smooth muscle cells : nox1 mediates angiotensin II-induced superoxide formation and redox-sensitive signaling pathways. Circ Res. 88 (9) 888-94 (2001)

43. Santos, C.X., Tanaka, L.Y., Wosniak, J., and Laurindo, F.R. Mechanisms and implications of reactive oxygen species generation during the unfolded protein response: roles of endoplasmic reticulum oxidoreductases, mitochondrial electron transport, and NADPH oxidase. Antioxid Redox Signal. 11 (10) 2409-27 (2009)

44. Laurindo, F.R., Fernandes, D.C., Amanso, A.M., Lopes, L.R., and Santos, C.X. Novel role of protein disulfide isomerase in the regulation of NADPH oxidase activity: pathophysiological implications in vascular diseases. Antioxid Redox Signal. 10 (6) 1101-13 (2008)

45. Santos, C.X., Stolf, B.S., Takemoto, P.V., Amanso, A.M., Lopes, L.R., Souza, E.B., Goto, H., and Laurindo, F.R. Protein disulfide isomerase (PDI) associates with $\mathrm{NADPH}$ oxidase and is required for phagocytosis of Leishmania chagasi promastigotes by macrophages. $J$ Leukoc Biol. 86 (4) 989-98 (2009)

46. Jay, D.B., Papaharalambus, C.A., Seidel-Rogol, B., Dikalova, A.E., Lassegue, B., and Griendling, K.K. Nox5 mediates PDGF-induced proliferation in human aortic smooth muscle cells. Free Radic Biol Med. 45 (3) 329-35 (2008)

47. Baysal, B.E. A phenotypic perspective on Mammalian oxygen sensor candidates. Ann N Y Acad Sci. 1073 221-33 (2006)

48. Palmer, R.M., Ashton, D.S., and Moncada, S. Vascular endothelial cells synthesize nitric oxide from L-arginine. Nature. 333 (6174) 664-6 (1988)

49. Hwang, J., Ing, M.H., Salazar, A., Lassegue, B., Griendling, K., Navab, M., Sevanian, A., and Hsiai, T.K. Pulsatile versus oscillatory shear stress regulates NADPH oxidase subunit expression: implication for native LDL oxidation. Circ Res. 93 (12) 1225-32 (2003) 
50. Price, D.T., Vita, J.A., and Keaney, J.F., Jr. Redox control of vascular nitric oxide bioavailability. Antioxid Redox Signal. 2 (4) 919-35 (2000)

51. Halliwell, B., Zhao, K., and Whiteman, M. Nitric oxide and peroxynitrite. The ugly, the uglier and the not so good: a personal view of recent controversies. Free Radic Res. 31 (6) 651-69 (1999)

52. Jeremy, J.Y., Yim, A.P., Wan, S., and Angelini, G.D. Oxidative stress, nitric oxide, and vascular disease. J Card Surg. 17 (4) 324-7 (2002)

53. Zou, M.H., Shi, C., and Cohen, R.A. Oxidation of the zinc-thiolate complex and uncoupling of endothelial nitric oxide synthase by peroxynitrite. J Clin Invest. 109 (6) 817$26(2002)$

54. Zou, M.H. Peroxynitrite and protein tyrosine nitration of prostacyclin synthase. Prostaglandins Other Lipid Mediat. 82 (1-4) 119-27 (2007)

55. Fujimoto, S., Asano, T., Sakai, M., Sakurai, K., Takagi, D., Yoshimoto, N., and Itoh, T. Mechanisms of hydrogen peroxide-induced relaxation in rabbit mesenteric small artery. Eur J Pharmacol. 412 (3) 291-300 (2001)

56. Gao, Y.J., Hirota, S., Zhang, D.W., Janssen, L.J., and Lee, R.M. Mechanisms of hydrogen-peroxide-induced biphasic response in rat mesenteric artery. Br J Pharmacol. 138 (6) 1085-92 (2003)

57. Burke, T.M. and Wolin, M.S. Hydrogen peroxide elicits pulmonary arterial relaxation and guanylate cyclase activation. Am J Physiol. 252 (4 Pt 2) H721-32 (1987)

58. Lucchesi, P.A., Belmadani, S., and Matrougui, K. Hydrogen peroxide acts as both vasodilator and vasoconstrictor in the control of perfused mouse mesenteric resistance arteries. J Hypertens. 23 (3) 571-9 (2005)

59. Liu, Y., Bubolz, A.H., Mendoza, S., Zhang, D.X., and Gutterman, D.D. H2O2 is the transferrable factor mediating flow-induced dilation in human coronary arterioles. Circ Res. 108 (5) 566-73 (2011)

60. Matoba, T., Shimokawa, H., Kubota, H., Morikawa, K., Fujiki, T., Kunihiro, I., Mukai, Y., Hirakawa, Y., and Takeshita, A. Hydrogen peroxide is an endothelium-derived hyperpolarizing factor in human mesenteric arteries. Biochem Biophys Res Commun. 290 (3) 909-13 (2002)

61. Matoba, T., Shimokawa, H., Nakashima, M., Hirakawa, Y., Mukai, Y., Hirano, K., Kanaide, H., and Takeshita, A. Hydrogen peroxide is an endothelium-derived hyperpolarizing factor in mice. J Clin Invest. 106 (12) 1521-30 (2000)

62. Suvorava, T., Lauer, N., Kumpf, S., Jacob, R., Meyer, W., and Kojda, G. Endogenous vascular hydrogen peroxide regulates arteriolar tension in vivo. Circulation. 112 (16) 248795 (2005)

63. Ellis, A., Pannirselvam, M., Anderson, T.J., and Triggle, C.R. Catalase has negligible inhibitory effects on endothelium-dependent relaxations in mouse isolated aorta and small mesenteric artery. Br J Pharmacol. 140 (7) 1193200 (2003)

64. Oeckler, R.A., Arcuino, E., Ahmad, M., Olson, S.C., and Wolin, M.S. Cytosolic NADH redox and thiol oxidation regulate pulmonary arterial force through ERK MAP kinase. Am J Physiol Lung Cell Mol Physiol. 288 (6) L1017-25 (2005)

65. Oeckler, R.A., Kaminski, P.M., and Wolin, M.S. Stretch enhances contraction of bovine coronary arteries via an NAD (P)H oxidase-mediated activation of the extracellular signal-regulated kinase mitogen-activated protein kinase cascade. Circ Res. 92 (1) 23-31 (2003)

66. Knock, G.A., Snetkov, V.A., Shaifta, Y., Connolly, M., Drndarski, S., Noah, A., Pourmahram, G.E., Becker, S., Aaronson, P.I., and Ward, J.P. Superoxide constricts rat pulmonary arteries via Rho-kinase-mediated $\mathrm{Ca}(2+)$ sensitization. Free Radic Biol Med. 46 (5) 633-42 (2009)

67. Larsen, B.T., Bubolz, A.H., Mendoza, S.A., Pritchard, K.A., Jr., and Gutterman, D.D. Bradykinin-induced dilation of human coronary arterioles requires NADPH oxidase-derived reactive oxygen species. Arterioscler Thromb Vasc Biol. 29 (5) $739-45$ (2009)

68. Schiffrin, E.L. Remodeling of resistance arteries in essential hypertension and effects of antihypertensive treatment. Am J Hypertens. 17 (12 Pt 1) 1192-200 (2004)

69. Rizzoni, D., Rodella, L., Porteri, E., Rezzani, R., Guelfi, D., Piccoli, A., Castellano, M., Muiesan, M.L., Bianchi, R., and Rosei, E.A. Time course of apoptosis in small resistance arteries of spontaneously hypertensive rats. J Hypertens. 18 (7) 885-91 (2000)

70. Ward, M.R., Pasterkamp, G., Yeung, A.C., and Borst, C. Arterial remodeling. Mechanisms and clinical implications. Circulation. 102 (10) 1186-91 (2000)

71. Hynes, R.O. The extracellular matrix: not just pretty fibrils. Science. 326 (5957) 1216-9 (2009)

72. Duprez, D.A. Role of the renin-angiotensin-aldosterone system in vascular remodeling and inflammation: a clinical review. J Hypertens. 24 (6) 983-91 (2006)

73. Marchesi, C., Ebrahimian, T., Angulo, O., Paradis, P., and Schiffrin, E.L. Endothelial nitric oxide synthase uncoupling and perivascular adipose oxidative stress and inflammation contribute to vascular dysfunction in a rodent model of metabolic syndrome. Hypertension. 54 (6) 1384-92 (2009)

74. Liu, J., Yang, F., Yang, X.P., Jankowski, M., and Pagano, P.J. NAD (P)H oxidase mediates angiotensin II-induced vascular macrophage infiltration and medial hypertrophy. Arterioscler Thromb Vasc Biol. 23 (5) 776-82 (2003)

75. Liu, J., Ormsby, A., Oja-Tebbe, N., and Pagano, P.J. Gene transfer of NAD (P)H oxidase inhibitor to the 
vascular adventitia attenuates medial smooth muscle hypertrophy. Circ Res. 95 (6) 587-94 (2004)

76. Dikalova, A., Clempus, R., Lassegue, B., Cheng, G., McCoy, J., Dikalov, S., San Martin, A., Lyle, A., Weber, D.S., Weiss, D., Taylor, W.R., Schmidt, H.H., Owens, G.K., Lambeth, J.D., and Griendling, K.K. Nox1 overexpression potentiates angiotensin II-induced hypertension and vascular smooth muscle hypertrophy in transgenic mice. Circulation. 112 (17) 2668-76 (2005)

77. Matsuno, K., Yamada, H., Iwata, K., Jin, D., Katsuyama, M., Matsuki, M., Takai, S., Yamanishi, K., Miyazaki, M., Matsubara, H., and Yabe-Nishimura, C. Nox1 is involved in angiotensin II-mediated hypertension: a study in Nox1-deficient mice. Circulation. 112 (17) 267785 (2005)

78. Janmey, P.A. The cytoskeleton and cell signaling: component localization and mechanical coupling. Physiol Rev. 78 (3) 763-81 (1998)

79. Mancini, A. and Di Battista, J.A. Transcriptional regulation of matrix metalloprotease gene expression in health and disease. Front Biosci. 11 423-46 (2006)

80. Rajagopalan, S., Meng, X.P., Ramasamy, S., Harrison, D.G., and Galis, Z.S. Reactive oxygen species produced by macrophage-derived foam cells regulate the activity of vascular matrix metalloproteinases in vitro. Implications for atherosclerotic plaque stability. J Clin Invest. 98 (11) 2572-9 (1996)

81. Gurjar, M.V., DeLeon, J., Sharma, R.V., and Bhalla, R.C. Mechanism of inhibition of matrix metalloproteinase-9 induction by NO in vascular smooth muscle cells. J Appl Physiol. 91 (3) 1380-6 (2001)

82. Browatzki, M., Larsen, D., Pfeiffer, C.A., Gehrke, S.G., Schmidt, J., Kranzhofer, A., Katus, H.A., and Kranzhofer, R. Angiotensin II stimulates matrix metalloproteinase secretion in human vascular smooth muscle cells via nuclear factor-kappaB and activator protein 1 in a redox-sensitive manner. J Vasc Res. 42 (5) 415-23 (2005)

83. Grote, K., Flach, I., Luchtefeld, M., Akin, E., Holland, S.M., Drexler, H., and Schieffer, B. Mechanical stretch enhances mRNA expression and proenzyme release of matrix metalloproteinase-2 (MMP-2) via NAD (P)H oxidasederived reactive oxygen species. Circ Res. 92 (11) e80-6 (2003)

84. Chu, X., Filali, M., Stanic, B., Takapoo, M., Sheehan, A., Bhalla, R., Lamb, F.S., and Miller, F.J., Jr. A critical role for chloride channel-3 (CIC-3) in smooth muscle cell activation and neointima formation. Arterioscler Thromb Vasc Biol. 31 (2) 345-51 (2011)

85. Al Ghouleh, I. and Pagano, P.J. Endosomal ClC-3 and Nox1: moving marksmen of redox signaling? Arterioscler Thromb Vasc Biol. 31 (2) 240-2 (2011)
86. Matsuda, J.J., Filali, M.S., Moreland, J.G., Miller, F.J., and Lamb, F.S. Activation of swelling-activated chloride current by tumor necrosis factor-alpha requires $\mathrm{ClC}-3$ dependent endosomal reactive oxygen production. $J$ Biol Chem. 285 (30) 22864-73 (2010)

87. Hecker, L., Vittal, R., Jones, T., Jagirdar, R., Luckhardt, T.R., Horowitz, J.C., Pennathur, S., Martinez, F.J., and Thannickal, V.J. NADPH oxidase-4 mediates myofibroblast activation and fibrogenic responses to lung injury. Nat Med. 15 (9) 1077-81 (2009)

88. Awad, A.E., Kandalam, V., Chakrabarti, S., Wang, X., Penninger, J.M., Davidge, S.T., Oudit, G.Y., and Kassiri, Z. Tumor necrosis factor induces matrix metalloproteinases in cardiomyocytes and cardiofibroblasts differentially via superoxide production in a PI3Kgamma-dependent manner. Am J Physiol Cell Physiol. 298 (3) C679-92

89. Kim, S.Y., Lee, J.G., Cho, W.S., Cho, K.H., Sakong, J., Kim, J.R., Chin, B.R., and Baek, S.H. Role of NADPH oxidase-2 in lipopolysaccharide-induced matrix metalloproteinase expression and cell migration. Immunol Cell Biol. 88 (2) 197-204 (2010)

90. Owens, G.K., Kumar, M.S., and Wamhoff, B.R. Molecular regulation of vascular smooth muscle cell differentiation in development and disease. Physiol Rev. 84 (3) $767-801$ (2004)

91. Finkel, T. Oxidant signals and oxidative stress. Curr Opin Cell Biol. 15 (2) 247-54 (2003)

92. Finkel, T. Reactive oxygen species and signal transduction. IUBMB Life. 52 (1-2) 3-6 (2001)

93. Finkel, T. and Holbrook, N.J. Oxidants, oxidative stress and the biology of ageing. Nature. 408 (6809) 239-47 (2000)

94. Sorescu, D., Somers, M.J., Lassegue, B., Grant, S., Harrison, D.G., and Griendling, K.K. Electron spin resonance characterization of the NAD (P)H oxidase in vascular smooth muscle cells. Free Radic Biol Med. 30 (6) 603-12 (2001)

95. Deshpande, N.N., Sorescu, D., Seshiah, P., UshioFukai, M., Akers, M., Yin, Q., and Griendling, K.K. Mechanism of hydrogen peroxide-induced cell cycle arrest in vascular smooth muscle. Antioxid Redox Signal. 4 (5) 845-54 (2002)

96. Martin-Garrido, A., Brown, D.I., Lyle, A.N., Dikalova, A., Seidel-Rogol, B., Lassegue, B., San Martin, A., and Griendling, K.K. NADPH oxidase 4 mediates TGF-betainduced smooth muscle alpha-actin via p38MAPK and serum response factor. Free Radic Biol Med. 50 (2) 354-62 (2011)

97. Clempus, R.E., Sorescu, D., Dikalova, A.E., Pounkova, L., Jo, P., Sorescu, G.P., Schmidt, H.H., Lassegue, B., and Griendling, K.K. Nox4 is required for maintenance of the 
differentiated vascular smooth muscle cell phenotype. Arterioscler Thromb Vasc Biol. 27 (1) 42-8 (2007)

98. Ismail, S., Sturrock, A., Wu, P., Cahill, B., Norman, K., Huecksteadt, T., Sanders, K., Kennedy, T., and Hoidal, J. NOX4 mediates hypoxia-induced proliferation of human pulmonary artery smooth muscle cells: the role of autocrine production of transforming growth factor-\{beta 1 and insulin-like growth factor binding protein-3. Am J Physiol Lung Cell Mol Physiol. 296 (3) L489-99 (2009)

99. Djordjevic, T., BelAiba, R.S., Bonello, S., Pfeilschifter, J., Hess, J., and Gorlach, A. Human urotensin II is a novel activator of NADPH oxidase in human pulmonary artery smooth muscle cells. Arterioscler Thromb Vasc Biol. 25 (3) 519-25 (2005)

100. Schroder, K., Wandzioch, K., Helmcke, I., and Brandes, R.P. Nox 4 acts as a switch between differentiation and proliferation in preadipocytes. Arterioscler Thromb Vasc Biol. 29 (2) 239-45 (2009)

101. Barnes, J.L. and Gorin, Y. Myofibroblast differentiation during fibrosis: role of NAD (P)H oxidases. Kidney Int. 79 (9) 944-956 (2010)

102. Li, P.F., Dietz, R., and von Harsdorf, R. Differential effect of hydrogen peroxide and superoxide anion on apoptosis and proliferation of vascular smooth muscle cells. Circulation. 96 (10) 3602-9 (1997)

103. Zafari, A.M., Ushio-Fukai, M., Akers, M., Yin, Q., Shah, A., Harrison, D.G., Taylor, W.R., and Griendling, K.K. Role of NADH/NADPH oxidase-derived $\mathrm{H} 2 \mathrm{O} 2$ in angiotensin II-induced vascular hypertrophy. Hypertension. 32 (3) 488-95 (1998)

104. Sundaresan, M., Yu, Z.X., Ferrans, V.J., Irani, K., and Finkel, T. Requirement for generation of $\mathrm{H} 2 \mathrm{O} 2$ for plateletderived growth factor signal transduction. Science. 270 (5234) 296-9 (1995)

105. Schroder, K. Isoform specific functions of Nox protein-derived reactive oxygen species in the vasculature. Curr Opin Pharmacol. 10 (2) 122-6 (2010)

106. Brandes, R.P. and Schroder, K. Differential vascular functions of Nox family NADPH oxidases. Curr Opin Lipidol. 19 (5) 513-8 (2008)

107. Irani, K. Oxidant signaling in vascular cell growth, death, and survival : a review of the roles of reactive oxygen species in smooth muscle and endothelial cell mitogenic and apoptotic signaling. Circ Res. 87 (3) 179-83 (2000)

108. Lee, M.Y., San Martin, A., Mehta, P.K., Dikalova, A.E., Garrido, A.M., Datla, S.R., Lyons, E., Krause, K.H., Banfi, B., Lambeth, J.D., Lassegue, B., and Griendling, K.K. Mechanisms of vascular smooth muscle NADPH oxidase 1 (Nox1) contribution to injury-induced neointimal formation. Arterioscler Thromb Vasc Biol. 29 (4) 480-7 (2009)

109. Menshikov, M., Plekhanova, O., Cai, H., Chalupsky, K., Parfyonova, Y., Bashtrikov, P., Tkachuk, V., and Berk, B.C. Urokinase plasminogen activator stimulates vascular smooth muscle cell proliferation via redox-dependent pathways. Arterioscler Thromb Vasc Biol. 26 (4) 801-7 (2006)

110. Ushio-Fukai, M., Zafari, A.M., Fukui, T., Ishizaka, N., and Griendling, K.K. p22phox is a critical component of the superoxide-generating NADH/NADPH oxidase system and regulates angiotensin II-induced hypertrophy in vascular smooth muscle cells. J Biol Chem. 271 (38) 23317-21 (1996)

111. Ushio-Fukai, M., Alexander, R.W., Akers, M., Yin, Q., Fujio, Y., Walsh, K., and Griendling, K.K. Reactive oxygen species mediate the activation of Akt/protein kinase B by angiotensin II in vascular smooth muscle cells. $J$ Biol Chem. 274 (32) 22699-704 (1999)

112. Garrido, A.M. and Griendling, K.K. NADPH oxidases and angiotensin II receptor signaling. Mol Cell Endocrinol. 302 (2) 148-58 (2009)

113. Niu, X.L., Madamanchi, N.R., Vendrov, A.E., Tchivilev, I., Rojas, M., Madamanchi, C., Brandes, R.P., Krause, K.H., Humphries, J., Smith, A., Burnand, K.G., and Runge, M.S. Nox activator 1: a potential target for modulation of vascular reactive oxygen species in atherosclerotic arteries. Circulation. 121 (4) 549-59 (2010)

114. Jiang, B., Xu, S., Hou, X., Pimentel, D.R., and Cohen, R.A. Angiotensin II differentially regulates interleukin-1-betainducible NO synthase (iNOS) and vascular cell adhesion molecule-1 (VCAM-1) expression: role of p38 MAPK. $J$ Biol Chem. 279 (19) 20363-8 (2004)

115. Bindoli, A., Fukuto, J.M., and Forman, H.J. Thiol chemistry in peroxidase catalysis and redox signaling. Antioxid Redox Signal. 10 (9) 1549-64 (2008)

116. Gutscher, M., Sobotta, M.C., Wabnitz, G.H., Ballikaya, S., Meyer, A.J., Samstag, Y., and Dick, T.P. Proximity-based protein thiol oxidation by $\mathrm{H} 2 \mathrm{O} 2$-scavenging peroxidases. $J$ Biol Chem. 284 (46) 31532-40 (2009)

117. Stanic, B., Katsuyama, M., and Miller, F.J., Jr. An oxidized extracellular oxidation-reduction state increases Nox1 expression and proliferation in vascular smooth muscle cells via epidermal growth factor receptor activation. Arterioscler Thromb Vasc Biol. 30 (11) 2234-41 (2010)

118. Li, J.M. and Shah, A.M. Intracellular localization and preassembly of the NADPH oxidase complex in cultured endothelial cells. J Biol Chem. 277 (22) 19952-60 (2002)

119. Van Buul, J.D., Fernandez-Borja, M., Anthony, E.C., and Hordijk, P.L. Expression and localization of NOX2 and 
NOX4 in primary human endothelial cells. Antioxid Redox Signal. 7 (3-4) 308-17 (2005)

120. Petry, A., Djordjevic, T., Weitnauer, M., Kietzmann, T., Hess, J., and Gorlach, A. NOX2 and NOX4 mediate proliferative response in endothelial cells. Antioxid Redox Signal. 8 (9-10) 1473-84 (2006)

121. Datla, S.R., Peshavariya, H., Dusting, G.J., Mahadev, K., Goldstein, B.J., and Jiang, F. Important role of Nox4 type NADPH oxidase in angiogenic responses in human microvascular endothelial cells in vitro. Arterioscler Thromb Vasc Biol. 27 (11) 2319-24 (2007)

122. Brandes, R.P. Role of NADPH oxidases in the control of vascular gene expression. Antioxid Redox Signal. 5 (6) 803-11 (2003)

123. Dourron, H.M., Jacobson, G.M., Park, J.L., Liu, J., Reddy, D.J., Scheel, M.L., and Pagano, P.J. Perivascular gene transfer of NADPH oxidase inhibitor suppresses angioplasty-induced neointimal proliferation of rat carotid artery. Am J Physiol Heart Circ Physiol. 288 (2) H946-53 (2005)

124. Haurani, M.J. and Pagano, P.J. Adventitial fibroblast reactive oxygen species as autacrine and paracrine mediators of remodeling: bellwether for vascular disease? Cardiovasc Res. 75 (4) 679-89 (2007)

125. Dickinson, B.C., Peltier, J., Stone, D., Schaffer, D.V., and Chang, C.J. Nox2 redox signaling maintains essential cell populations in the brain. Nat Chem Biol. 7 (2) 106-12 (2010)

126. San Martin, A. and Griendling, K.K. Redox control of vascular smooth muscle migration. Antioxid Redox Signal. 12 (5) 625-40 (2010)

127. Weber, D.S., Taniyama, Y., Rocic, P., Seshiah, P.N., Dechert, M.A., Gerthoffer, W.T., and Griendling, K.K. Phosphoinositide-dependent kinase 1 and p21-activated protein kinase mediate reactive oxygen species-dependent regulation of platelet-derived growth factor-induced smooth muscle cell migration. Circ Res. 94 (9) 1219-26 (2004)

128. San Martin, A., Lee, M.Y., Williams, H.C., Mizuno, K., Lassegue, B., and Griendling, K.K. Dual regulation of cofilin activity by LIM kinase and Slingshot-1L phosphatase controls platelet-derived growth factorinduced migration of human aortic smooth muscle cells. Circ Res. 102 (4) 432-8 (2008)

129. Schroder, K., Kohnen, A., Aicher, A., Liehn, E.A., Buchse, T., Stein, S., Weber, C., Dimmeler, S., and Brandes, R.P. NADPH oxidase Nox2 is required for hypoxia-induced mobilization of endothelial progenitor cells. Circ Res. 105 (6) 537-44 (2009)

130. Bae, Y.S., Lee, J.H., Choi, S.H., Kim, S., Almazan, F., Witztum, J.L., and Miller, Y.I. Macrophages generate reactive oxygen species in response to minimally oxidized low-density lipoprotein: toll-like receptor 4- and spleen tyrosine kinase-dependent activation of NADPH oxidase 2. Circ Res. 104 (2) 210-8, 21p following 218 (2009)

131. Ushio-Fukai, M., Tang, Y., Fukai, T., Dikalov, S.I., Ma, Y., Fujimoto, M., Quinn, M.T., Pagano, P.J., Johnson, C., and Alexander, R.W. Novel role of gp91 (phox)containing NAD (P)H oxidase in vascular endothelial growth factor-induced signaling and angiogenesis. Circ Res. 91 (12) 1160-7 (2002)

132. Brandes, R.P., Viedt, C., Nguyen, K., Beer, S., Kreuzer, J., Busse, R., and Gorlach, A. Thrombin-induced MCP-1 expression involves activation of the p22phoxcontaining NADPH oxidase in human vascular smooth muscle cells. Thromb Haemost. 85 (6) 1104-10 (2001)

133. ten Freyhaus, H., Huntgeburth, M., Wingler, K., Schnitker, J., Baumer, A.T., Vantler, M., Bekhite, M.M., Wartenberg, M., Sauer, H., and Rosenkranz, S. Novel Nox inhibitor VAS2870 attenuates PDGF-dependent smooth muscle cell chemotaxis, but not proliferation. Cardiovasc Res. 71 (2) 331-41 (2006)

134. Rodriguez, A.I., Gangopadhyay, A., Kelley, E.E., Pagano, P.J., Zuckerbraun, B.S., and Bauer, P.M. HO-1 and $\mathrm{CO}$ decrease platelet-derived growth factor-induced vascular smooth muscle cell migration via inhibition of Nox1. Arterioscler Thromb Vasc Biol. 30 (1) 98-104 (2010)

135. San Martin, A.L.M.G.K.K. Novel Nox1-mediated mechanism of SSH1L activation in VSMC. Role in Cell Migration. Atherosclerosis, Thrombosis and Vascular Biology. 28 (e109) (2008)

136. Schroder, K., Helmcke, I., Palfi, K., Krause, K.H., Busse, R., and Brandes, R.P. Nox1 mediates basic fibroblast growth factor-induced migration of vascular smooth muscle cells. Arterioscler Thromb Vasc Biol. 27 (8) 1736-43 (2007)

137. Shinohara, M., Adachi, Y., Mitsushita, J., Kuwabara, M., Nagasawa, A., Harada, S., Furuta, S., Zhang, Y., Seheli, K., Miyazaki, H., and Kamata, T. Reactive oxygen generated by NADPH oxidase 1 (Nox1) contributes to cell invasion by regulating matrix metalloprotease- 9 production and cell migration. J Biol Chem. 285 (7) 4481-8 (2010)

138. Sadok, A., Pierres, A., Dahan, L., Prevot, C., Lehmann, M., and Kovacic, H. NADPH oxidase 1 controls the persistence of directed cell migration by a Rhodependent switch of alpha2/alpha3 integrins. Mol Cell Biol. 29 (14) 3915-28 (2009)

139. Meng, D., Lv, D.D., and Fang, J. Insulin-like growth factor-I induces reactive oxygen species production and cell migration through Nox4 and Rac1 in vascular smooth muscle cells. Cardiovasc Res. 80 (2) 299-308 (2008)

140. Tobar, N., Guerrero, J., Smith, P.C., and Martinez, J. NOX4-dependent ROS production by stromal mammary 
cells modulates epithelial MCF-7 cell migration. $\mathrm{Br} J$ Cancer. 103 (7) 1040-7 (2010)

141. Haurani, M.J., Cifuentes, M.E., Shepard, A.D., and Pagano, P.J. Nox4 oxidase overexpression specifically decreases endogenous Nox4 mRNA and inhibits angiotensin II-induced adventitial myofibroblast migration. Hypertension. 52 (1) 143-9 (2008)

142. Tong, X. and Schroder, K. NADPH oxidases are responsible for the failure of nitric oxide to inhibit migration of smooth muscle cells exposed to high glucose. Free Radic Biol Med. 47 (11) 1578-83 (2009)

143. Tong, X., Hou, X., Jourd'heuil, D., Weisbrod, R.M., and Cohen, R.A. Upregulation of Nox 4 by TGF $\{$ beta $\} 1$ oxidizes SERCA and inhibits NO in arterial smooth muscle of the prediabetic Zucker rat. Circ Res. 107 (8) 975-83 (2010)

144. Yorimitsu, T. and Klionsky, D.J. Eating the endoplasmic reticulum: quality control by autophagy. Trends Cell Biol. 17 (6) 279-85 (2007)

145. Nishida, K., Yamaguchi, O., and Otsu, K. Crosstalk between autophagy and apoptosis in heart disease. Circ Res. 103 (4) 343-51 (2008)

146. Filomeni, G. and Ciriolo, M.R. Redox control of apoptosis: an update. Antioxid Redox Signal. 8 (11-12) 2187-92 (2006)

147. Terada, L.S. Specificity in reactive oxidant signaling: think globally, act locally. J Cell Biol. 174 (5) 615-23 (2006)

148. Basuroy, S., Bhattacharya, S., Leffler, C.W., and Parfenova, H. Nox4 NADPH oxidase mediates oxidative stress and apoptosis caused by TNF-alpha in cerebral vascular endothelial cells. Am J Physiol Cell Physiol. 296 (3) C422-32 (2009)

149. Dong, F., Zhang, X., Li, S.Y., Zhang, Z., Ren, Q., Culver, B., and Ren, J. Possible involvement of NADPH oxidase and $\mathrm{JNK}$ in homocysteine-induced oxidative stress and apoptosis in human umbilical vein endothelial cells. Cardiovasc Toxicol. 5 (1) 9-20 (2005)

150. Shin, H.K., Kim, Y.K., Kim, K.Y., Lee, J.H., and Hong, K.W. Remnant lipoprotein particles induce apoptosis in endothelial cells by NAD (P)H oxidase-mediated production of superoxide and cytokines via lectin-like oxidized low-density lipoprotein receptor-1 activation: prevention by cilostazol. Circulation. 109 (8) 1022-8 (2004)

151. Van Laethem, A., Nys, K., Van Kelst, S., Claerhout, S., Ichijo, H., Vandenheede, J.R., Garmyn, M., and Agostinis, P. Apoptosis signal regulating kinase-1 connects reactive oxygen species to p38 MAPK-induced mitochondrial apoptosis in UVB-irradiated human keratinocytes. Free Radic Biol Med. 41 (9) 1361-71 (2006)
152. Qin, F., Patel, R., Yan, C., and Liu, W. NADPH oxidase is involved in angiotensin II-induced apoptosis in H9C2 cardiac muscle cells: effects of apocynin. Free Radic Biol Med. 40 (2) 236-46 (2006)

153. Ago, T., Kuroda, J., Pain, J., Fu, C., Li, H., and Sadoshima, J. Upregulation of Nox4 by hypertrophic stimuli promotes apoptosis and mitochondrial dysfunction in cardiac myocytes. Circ Res. 106 (7) 1253-64 (2010)

154. Kuroda, J., Ago, T., Matsushima, S., Zhai, P., Schneider, M.D., and Sadoshima, J. NADPH oxidase 4 (Nox4) is a major source of oxidative stress in the failing heart. Proc Natl Acad Sci U S A. 107 (35) 15565-70 (2010)

155. Johnson, T.M., Yu, Z.X., Ferrans, V.J., Lowenstein, R.A., and Finkel, T. Reactive oxygen species are downstream mediators of p53-dependent apoptosis. Proc Natl Acad Sci U S A. 93 (21) 11848-52 (1996)

156. Speir, E., Modali, R., Huang, E.S., Leon, M.B., Shawl, F., Finkel, T., and Epstein, S.E. Potential role of human cytomegalovirus and p53 interaction in coronary restenosis. Science. 265 (5170) 391-4 (1994)

157. Li, P.F., Dietz, R., and von Harsdorf, R. Reactive oxygen species induce apoptosis of vascular smooth muscle cell. FEBS Lett. 404 (2-3) 249-52 (1997)

158. Li, Y., Zhang, F., Nagai, N., Tang, Z., Zhang, S., Scotney, P., Lennartsson, J., Zhu, C., Qu, Y., Fang, C., Hua, J., Matsuo, O., Fong, G.H., Ding, H., Cao, Y., Becker, K.G., Nash, A., Heldin, C.H., and Li, X. VEGF-B inhibits apoptosis via VEGFR-1-mediated suppression of the expression of BH3-only protein genes in mice and rats. $J$ Clin Invest. 118 (3) 913-23 (2008)

159. Rutkowski, D.T., Wu, J., Back, S.H., Callaghan, M.U., Ferris, S.P., Iqbal, J., Clark, R., Miao, H., Hassler, J.R., Fornek, J., Katze, M.G., Hussain, M.M., Song, B., Swathirajan, J., Wang, J., Yau, G.D., and Kaufman, R.J. UPR pathways combine to prevent hepatic steatosis caused by ER stress-mediated suppression of transcriptional master regulators. Dev Cell. 15 (6) 829-40 (2008)

160. Rutkowski, D.T., Arnold, S.M., Miller, C.N., Wu, J., Li, J., Gunnison, K.M., Mori, K., Sadighi Akha, A.A., Raden, D., and Kaufman, R.J. Adaptation to ER stress is mediated by differential stabilities of pro-survival and proapoptotic mRNAs and proteins. PLoS Biol. 4 (11) e374 (2006)

161. Minamino, T. and Kitakaze, M. ER stress in cardiovascular disease. J Mol Cell Cardiol. 48 (6) 1105-10 (2010)

162. Kitakaze, M. and Tsukamoto, O. What is the role of ER stress in the heart? Introduction and series overview. Circ Res. 107 (1) 15-8 (2010)

163. Heath-Engel, H.M., Chang, N.C., and Shore, G.C. The endoplasmic reticulum in apoptosis and autophagy: role of 
the BCL-2 protein family. Oncogene. 27 (50) 6419-33 (2008)

164. Merksamer, P.I., Trusina, A., and Papa, F.R. Realtime redox measurements during endoplasmic reticulum stress reveal interlinked protein folding functions. Cell. 135 (5) 933-47 (2008)

165. Malhotra, J.D. and Kaufman, R.J. Endoplasmic reticulum stress and oxidative stress: a vicious cycle or a double-edged sword? Antioxid Redox Signal. 9 (12) 2277 93 (2007)

166. Amanso, A.M., Debbas, V., and Laurindo, F.R. Proteasome inhibition represses unfolded protein response and Nox4, sensitizing vascular cells to endoplasmic reticulum stress-induced death. PLoS One. 6 (1) e14591 (2011)

167. Younce, C.W. and Kolattukudy, P.E. MCP-1 causes cardiomyoblast death via autophagy resulting from ER stress caused by oxidative stress generated by inducing a novel zinc-finger protein, MCPIP. Biochem J. 426 (1) 43$53(2010)$

168. Li, G., Scull, C., Ozcan, L., and Tabas, I. NADPH oxidase links endoplasmic reticulum stress, oxidative stress, and PKR activation to induce apoptosis. J Cell Biol. 191 (6) 1113-25 (2010)

169. Loughlin, D.T. and Artlett, C.M. Precursor of advanced glycation end products mediates ER-stressinduced caspase- 3 activation of human dermal fibroblasts through NAD (P)H oxidase 4. PLoS One. 5 (6) e11093 (2011)

170. Li, J., Zhu, H., Shen, E., Wan, L., Arnold, J.M., and Peng, T. Deficiency of rac1 blocks NADPH oxidase activation, inhibits endoplasmic reticulum stress, and reduces myocardial remodeling in a mouse model of type 1 diabetes. Diabetes. 59 (8) 2033-42 (2010)

171. Wu, R.F., Ma, Z., Liu, Z., and Terada, L.S. Nox4derived $\mathrm{H} 2 \mathrm{O} 2$ mediates endoplasmic reticulum signaling through local Ras activation. Mol Cell Biol. 30 (14) 355368 (2010)

172. Pedruzzi, E., Guichard, C., Ollivier, V., Driss, F., Fay, M., Prunet, C., Marie, J.C., Pouzet, C., Samadi, M., Elbim, C., O'Dowd, Y., Bens, M., Vandewalle, A., GougerotPocidalo, M.A., Lizard, G., and Ogier-Denis, E. NAD (P)H oxidase Nox-4 mediates 7-ketocholesterol-induced endoplasmic reticulum stress and apoptosis in human aortic smooth muscle cells. Mol Cell Biol. 24 (24) 10703-17 (2004)

173. Tabas, I. and Ron, D. Integrating the mechanisms of apoptosis induced by endoplasmic reticulum stress. Nat Cell Biol. 13 (3) 184-90 (2011)

174. Gu, F., Nguyen, D.T., Stuible, M., Dube, N., Tremblay, M.L., and Chevet, E. Protein-tyrosine phosphatase 1B potentiates IRE1 signaling during endoplasmic reticulum stress. J Biol Chem. 279 (48) 49689-93 (2004)

175. Chen, K., Kirber, M.T., Xiao, H., Yang, Y., and Keaney, J.F., Jr. Regulation of ROS signal transduction by NADPH oxidase 4 localization. J Cell Biol. 181 (7) 112939 (2008)

176. Ben Mkaddem, S., Pedruzzi, E., Werts, C., Coant, N., Bens, M., Cluzeaud, F., Goujon, J.M., Ogier-Denis, E., and Vandewalle, A. Heat shock protein gp96 and NAD (P)H oxidase 4 play key roles in Toll-like receptor 4-activated apoptosis during renal ischemia/reperfusion injury. Cell Death Differ. 17 (9) 1474-85 (2010)

177. Huang, J. and Brumell, J.H. NADPH oxidases contribute to autophagy regulation. Autophagy. 5 (6) 887-9 (2009)

178. Li, J., Ni, M., Lee, B., Barron, E., Hinton, D.R., and Lee, A.S. The unfolded protein response regulator GRP78/BiP is required for endoplasmic reticulum integrity and stress-induced autophagy in mammalian cells. Cell Death Differ. 15 (9) 1460-71 (2008)

179. Huang, J., Canadien, V., Lam, G.Y., Steinberg, B.E., Dinauer, M.C., Magalhaes, M.A., Glogauer, M., Grinstein, S., and Brumell, J.H. Activation of antibacterial autophagy by NADPH oxidases. Proc Natl Acad Sci U S A. 106 (15) 6226-31 (2009)

180. Semenza, G.L. Life with oxygen. Science. 318 (5847) 62-4 (2007)

181. Semenza, G.L. Regulation of oxygen homeostasis by hypoxia-inducible factor 1. Physiology (Bethesda). 24 97106 (2009)

182. Majmundar, A.J., Wong, W.J., and Simon, M.C. Hypoxia-inducible factors and the response to hypoxic stress. Mol Cell. 40 (2) 294-309 (2010)

183. Maxwell, P.H., Wiesener, M.S., Chang, G.W., Clifford, S.C., Vaux, E.C., Cockman, M.E., Wykoff, C.C., Pugh, C.W., Maher, E.R., and Ratcliffe, P.J. The tumour suppressor protein VHL targets hypoxia-inducible factors for oxygen-dependent proteolysis. Nature. 399 (6733) 2715 (1999)

184. Kelly, B.D., Hackett, S.F., Hirota, K., Oshima, Y., Cai, Z., Berg-Dixon, S., Rowan, A., Yan, Z., Campochiaro, P.A., and Semenza, G.L. Cell type-specific regulation of angiogenic growth factor gene expression and induction of angiogenesis in nonischemic tissue by a constitutively active form of hypoxia-inducible factor 1. Circ Res. 93 (11) 1074-81 (2003)

185. Bosch-Marce, M., Okuyama, H., Wesley, J.B., Sarkar, K., Kimura, H., Liu, Y.V., Zhang, H., Strazza, M., Rey, S., Savino, L., Zhou, Y.F., McDonald, K.R., Na, Y., Vandiver, S., Rabi, A., Shaked, Y., Kerbel, R., Lavallee, T., and Semenza, G.L. Effects of aging and hypoxia-inducible 
factor-1 activity on angiogenic cell mobilization and recovery of perfusion after limb ischemia. Circ Res. 101 (12) $1310-8$ (2007)

186. Fu, X.W., Wang, D., Nurse, C.A., Dinauer, M.C., and Cutz, E. NADPH oxidase is an $\mathrm{O} 2$ sensor in airway chemoreceptors: evidence from $\mathrm{K}+$ current modulation in wild-type and oxidase-deficient mice. Proc Natl Acad Sci US A. 97 (8) 4374-9 (2000)

187. Archer, S.L., Reeve, H.L., Michelakis, E., Puttagunta, L., Waite, R., Nelson, D.P., Dinauer, M.C., and Weir, E.K. $\mathrm{O} 2$ sensing is preserved in mice lacking the gp91 phox subunit of NADPH oxidase. Proc Natl Acad Sci U S A. 96 (14) 7944-9 (1999)

188. Goyal, P., Weissmann, N., Grimminger, F., Hegel, C., Bader, L., Rose, F., Fink, L., Ghofrani, H.A., Schermuly, R.T., Schmidt, H.H., Seeger, W., and Hanze, J. Upregulation of NAD (P)H oxidase 1 in hypoxia activates hypoxia-inducible factor 1 via increase in reactive oxygen species. Free Radic Biol Med. 36 (10) 1279-88 (2004)

189. Diebold, I., Petry, A., Hess, J., and Gorlach, A. The NADPH oxidase subunit NOX4 is a new target gene of the hypoxia-inducible factor-1. Mol Biol Cell. 21 (12) 2087-96 (2010)

190. Park, S.J., Chun, Y.S., Park, K.S., Kim, S.J., Choi, S.O., Kim, H.L., and Park, J.W. Identification of subdomains in NADPH oxidase-4 critical for the oxygendependent regulation of TASK-1 K+ channels. Am J Physiol Cell Physiol. 297 (4) C855-64 (2009)

191. Lee, Y.M., Kim, B.J., Chun, Y.S., So, I., Choi, H., Kim, M.S., and Park, J.W. NOX4 as an oxygen sensor to regulate TASK-1 activity. Cell Signal. 18 (4) 499-507 (2006)

192. Stenmark, K.R., Fagan, K.A., and Frid, M.G. Hypoxia-induced pulmonary vascular remodeling: cellular and molecular mechanisms. Circ Res. 99 (7) 675-91 (2006)

193. Coggins, M.P. and Bloch, K.D. Nitric oxide in the pulmonary vasculature. Arterioscler Thromb Vasc Biol. 27 (9) $1877-85$ (2007)

194. Liu, J.Q., Sham, J.S., Shimoda, L.A., Kuppusamy, P., and Sylvester, J.T. Hypoxic constriction and reactive oxygen species in porcine distal pulmonary arteries. $\mathrm{Am} J$ Physiol Lung Cell Mol Physiol. 285 (2) L322-33 (2003)

195. Van Rheen, Z., Fattman, C., Domarski, S., Majka, S., Klemm, D., Stenmark, K.R., and Nozik-Grayck, E. Lung extracellular superoxide dismutase overexpression lessens bleomycin-induced pulmonary hypertension and vascular remodeling. Am J Respir Cell Mol Biol. 44 (4) 500-8 (2011)

196. Dennis, K.E., Aschner, J.L., Milatovic, D., Schmidt, J.W., Aschner, M., Kaplowitz, M.R., Zhang, Y., and Fike, C.D. NADPH oxidases and reactive oxygen species at different stages of chronic hypoxia-induced pulmonary hypertension in newborn piglets. Am J Physiol Lung Cell Mol Physiol. 297 (4) L596-607 (2009)

197. Liu, J.Q., Erbynn, E.M., and Folz, R.J. Chronic hypoxia-enhanced murine pulmonary vasoconstriction: role of superoxide and gp91phox. Chest. 128 (6 Suppl) 594S596S (2005)

198. Sanders, K.A., Sundar, K.M., He, L., Dinger, B., Fidone, S., and Hoidal, J.R. Role of components of the phagocytic NADPH oxidase in oxygen sensing. $J$ Appl Physiol. 93 (4) 1357-64 (2002)

199. Fresquet, F., Pourageaud, F., Leblais, V., Brandes, R.P., Savineau, J.P., Marthan, R., and Muller, B. Role of reactive oxygen species and gp91phox in endothelial dysfunction of pulmonary arteries induced by chronic hypoxia. Br J Pharmacol. 148 (5) 714-23 (2006)

200. Nisbet, R.E., Graves, A.S., Kleinhenz, D.J., Rupnow, H.L., Reed, A.L., Fan, T.H., Mitchell, P.O., Sutliff, R.L., and Hart, C.M. The role of NADPH oxidase in chronic intermittent hypoxia-induced pulmonary hypertension in mice. Am J Respir Cell Mol Biol. 40 (5) 601-9 (2009)

201. Mittal, M., Roth, M., Konig, P., Hofmann, S., Dony, E., Goyal, P., Selbitz, A.C., Schermuly, R.T., Ghofrani, H.A., Kwapiszewska, G., Kummer, W., Klepetko, W., Hoda, M.A., Fink, L., Hanze, J., Seeger, W., Grimminger, F., Schmidt, H.H., and Weissmann, N. Hypoxia-dependent regulation of nonphagocytic NADPH oxidase subunit NOX4 in the pulmonary vasculature. Circ Res. 101 (3) 258-67 (2007)

202. Ahmad, M., Kelly, M.R., Zhao, X., Kandhi, S., and Wolin, M.S. Roles for Nox4 in the contractile response of bovine pulmonary arteries to hypoxia. Am J Physiol Heart Circ Physiol. 298 (6) H1879-88

203. Diebold, I., Petry, A., Hess, J., and Gorlach, A. The NADPH oxidase subunit NOX4 is a new target gene of the hypoxia-inducible factor-1. Mol Biol Cell. 21 (12) 2087-96 (2010)

204. Diebold, I., Flugel, D., Becht, S., Belaiba, R.S., Bonello, S., Hess, J., Kietzmann, T., and Gorlach, A. The hypoxia-inducible factor-2alpha is stabilized by oxidative stress involving NOX4. Antioxid Redox Signal. 13 (4) $425-$ $36(2010)$

205. Lu, X., Murphy, T.C., Nanes, M.S., and Hart, C.M. PPAR \{gamma $\}$ regulates hypoxia-induced Nox4 expression in human pulmonary artery smooth muscle cells through NF-\{kappa\}B. Am J Physiol Lung Cell Mol Physiol. 299 (4) L559-66 (2010)

206. Lusis, A.J. Atherosclerosis. Nature. 407 (6801) 23341 (2000)

207. Heinloth, A., Heermeier, K., Raff, U., Wanner, C., and Galle, J. Stimulation of NADPH oxidase by oxidized low- 
density lipoprotein induces proliferation of human vascular endothelial cells. J Am Soc Nephrol. 11 (10) 1819-25 (2000)

208. Aviram, M., Rosenblat, M., Etzioni, A., and Levy, R. Activation of NADPH oxidase required for macrophagemediated oxidation of low-density lipoprotein. Metabolism. 45 (9) 1069-79 (1996)

209. Barry-Lane, P.A., Patterson, C., van der Merwe, M., Hu, Z., Holland, S.M., Yeh, E.T., and Runge, M.S. p47phox is required for atherosclerotic lesion progression in ApoE (-/-) mice. J Clin Invest. 108 (10) 1513-22 (2001)

210. Hsich, E., Segal, B.H., Pagano, P.J., Rey, F.E., Paigen, B., Deleonardis, J., Hoyt, R.F., Holland, S.M., and Finkel, T. Vascular effects following homozygous disruption of p47 (phox) : An essential component of NADPH oxidase. Circulation. 101 (11) 1234-6 (2000)

211. Sheehan, A.L., Carrell, S., Johnson, B., Stanic, B., Banfi, B., and Miller, F.J., Jr. Role for Nox1 NADPH oxidase in atherosclerosis. Atherosclerosis (2011)

212. Zhou, M.S., Hernandez Schulman, I., Pagano, P.J., Jaimes, E.A., and Raij, L. Reduced NAD (P)H oxidase in low renin hypertension: link among angiotensin II, atherogenesis, and blood pressure. Hypertension. 47 (1) 816 (2006)

213. Tabas, I. The Role of Endoplasmic Reticulum Stress in the Progression of Atherosclerosis. Circulation Research. 107 (7) 839-850 (2010)

214. De Meyer, G.R.Y. and Martinet, W. Autophagy in the cardiovascular system. Biochimica Et Biophysica ActaMolecular Cell Research. 1793 (9) 1485-1495 (2009)

215. Martinet, W. and De Meyer, G.R.Y. Autophagy in Atherosclerosis A Cell Survival and Death Phenomenon With Therapeutic Potential. Circulation Research. 104 (3) 304-317 (2009)

216. Myoishi, M., Hao, H., Minamino, T., Watanabe, K., Nishihira, K., Hatakeyama, K., Asada, Y., Okada, K.I., Ishibashi-Ueda, H., Gabbiani, G., Bochaton-Piallat, M.L., Mochizuki, N., and Kitakaze, M. Increased endoplasmic reticulum stress in atherosclerotic plaques associated with acute coronary syndrome. Circulation. 116 (11) 1226-1233 (2007)

217. Thorp, E., Li, G., Seimon, T.A., Kuriakose, G., Ron, D., and Tabas, I. Reduced apoptosis and plaque necrosis in advanced atherosclerotic lesions of Apoe-/- and Ldlr-/mice lacking CHOP. Cell Metab. 9 (5) 474-81 (2009)

218. Ron, D. and Walter, P. Signal integration in the endoplasmic reticulum unfolded protein response. Nat Rev Mol Cell Biol. 8 (7) 519-29 (2007)

219. Park, H.S., Jung, H.Y., Park, E.Y., Kim, J., Lee, W.J., and Bae, Y.S. Cutting edge: direct interaction of TLR4 with
NAD (P)H oxidase 4 isozyme is essential for lipopolysaccharide-induced production of reactive oxygen species and activation of NF-kappa B. J Immunol. 173 (6) 3589-93 (2004)

220. Park, H.S., Chun, J.N., Jung, H.Y., Choi, C., and Bae, Y.S. Role of NADPH oxidase 4 in lipopolysaccharideinduced proinflammatory responses by human aortic endothelial cells. Cardiovasc Res. 72 (3) 447-55 (2006)

221. Maloney, E., Sweet, I.R., Hockenbery, D.M., Pham, M., Rizzo, N.O., Tateya, S., Handa, P., Schwartz, M.W., and Kim, F. Activation of NF-kappaB by palmitate in endothelial cells: a key role for NADPH oxidase-derived superoxide in response to TLR4 activation. Arterioscler Thromb Vasc Biol. 29 (9) 1370-5 (2009)

222. Cai, H., Griendling, K.K., and Harrison, D.G. The vascular NAD (P)H oxidases as therapeutic targets in cardiovascular diseases. Trends Pharmacol Sci. 24 (9) 4718 (2003)

223. Khatri, J.J., Johnson, C., Magid, R., Lessner, S.M., Laude, K.M., Dikalov, S.I., Harrison, D.G., Sung, H.J., Rong, Y., and Galis, Z.S. Vascular oxidant stress enhances progression and angiogenesis of experimental atheroma. Circulation. 109 (4) 520-5 (2004)

224. Szocs, K., Lassegue, B., Sorescu, D., Hilenski, L.L., Valppu, L., Couse, T.L., Wilcox, J.N., Quinn, M.T., Lambeth, J.D., and Griendling, K.K. Upregulation of Noxbased NAD (P)H oxidases in restenosis after carotid injury. Arterioscler Thromb Vasc Biol. 22 (1) 21-7 (2002)

225. Diebold, I., Djordjevic, T., Petry, A., Hatzelmann, A., Tenor, H., Hess, J., and Gorlach, A. Phosphodiesterase 2 mediates redox-sensitive endothelial cell proliferation and angiogenesis by thrombin via Rac1 and NADPH oxidase 2. Circ Res. 104 (10) 1169-77 (2009)

226. Al-Shabrawey, M., Bartoli, M., El-Remessy, A.B., Platt, D.H., Matragoon, S., Behzadian, M.A., Caldwell, R.W., and Caldwell, R.B. Inhibition of NAD (P)H oxidase activity blocks vascular endothelial growth factor overexpression and neovascularization during ischemic retinopathy. Am J Pathol. 167 (2) 599-607 (2005)

227. Tojo, T., Ushio-Fukai, M., Yamaoka-Tojo, M., Ikeda, S., Patrushev, N., and Alexander, R.W. Role of gp91phox (Nox2)-containing NAD (P)H oxidase in angiogenesis in response to hindlimb ischemia. Circulation. 111 (18) 234755 (2005)

228. Urao, N., Inomata, H., Razvi, M., Kim, H.W., Wary, K., McKinney, R., Fukai, T., and Ushio-Fukai, M. Role of nox2-based NADPH oxidase in bone marrow and progenitor cell function involved in neovascularization induced by hindlimb ischemia. Circ Res. 103 (2) 212-20 (2008)

229. Straub, A.C., Clark, K.A., Ross, M.A., Chandra, A.G., Li, S., Gao, X., Pagano, P.J., Stolz, D.B., and Barchowsky, 
A. Arsenic-stimulated liver sinusoidal capillarization in mice requires NADPH oxidase-generated superoxide. $J$ Clin Invest. 118 (12) 3980-9 (2008)

230. Arbiser, J.L., Petros, J., Klafter, R., Govindajaran, B., McLaughlin, E.R., Brown, L.F., Cohen, C., Moses, M., Kilroy, S., Arnold, R.S., and Lambeth, J.D. Reactive oxygen generated by Nox 1 triggers the angiogenic switch. Proc Natl Acad Sci U S A. 99 (2) 715-20 (2002)

231. Garrido-Urbani, S., Jemelin, S., Deffert, C., Carnesecchi, S., Basset, O., Szyndralewiez, C., Heitz, F., Page, P., Montet, X., Michalik, L., Arbiser, J., Ruegg, C., Krause, K.H., and Imhof, B. Targeting Vascular NADPH Oxidase 1 Blocks Tumor Angiogenesis through a PPARalpha Mediated Mechanism. PLoS One. 6 (2) e14665 (2011)

232. Reed, R., Kolz, C., Potter, B., and Rocic, P. The mechanistic basis for the disparate effects of angiotensin II on coronary collateral growth. Arterioscler Thromb Vasc Biol. 28 (1) 61-7 (2008)

233. Teng, R.J., Eis, A., Bakhutashvili, I., Arul, N., and Konduri, G.G. Increased superoxide production contributes to the impaired angiogenesis of fetal pulmonary arteries with in utero pulmonary hypertension. Am J Physiol Lung Cell Mol Physiol. 297 (1) L184-95 (2009)

234. Sonta, T., Inoguchi, T., Tsubouchi, H., Sekiguchi, N., Kobayashi, K., Matsumoto, S., Utsumi, H., and Nawata, H. Evidence for contribution of vascular NAD (P)H oxidase to increased oxidative stress in animal models of diabetes and obesity. Free Radic Biol Med. 37 (1) 115-23 (2004)

235. Furukawa, S., Fujita, T., Shimabukuro, M., Iwaki, M., Yamada, Y., Nakajima, Y., Nakayama, O., Makishima, M., Matsuda, M., and Shimomura, I. Increased oxidative stress in obesity and its impact on metabolic syndrome. $J$ Clin Invest. 114 (12) 1752-61 (2004)

236. San Martin, A., Du, P., Dikalova, A., Lassegue, B., Aleman, M., Gongora, M.C., Brown, K., Joseph, G., Harrison, D.G., Taylor, W.R., Jo, H., and Griendling, K.K. Reactive oxygen species-selective regulation of aortic inflammatory gene expression in Type 2 diabetes. $A m J$ Physiol Heart Circ Physiol. 292 (5) H2073-82 (2007)

237. San Martin, A., Foncea, R., Laurindo, F.R., Ebensperger, R., Griendling, K.K., and Leighton, F. Nox1based NADPH oxidase-derived superoxide is required for VSMC activation by advanced glycation end-products. Free Radic Biol Med. 42 (11) 1671-9 (2007)

238. Privratsky, J.R., Wold, L.E., Sowers, J.R., Quinn, M.T., and Ren, J. AT1 blockade prevents glucose-induced cardiac dysfunction in ventricular myocytes: role of the AT1 receptor and NADPH oxidase. Hypertension. 42 (2) 206-12 (2003)

239. Zhang, L., Zalewski, A., Liu, Y., Mazurek, T., Cowan, S., Martin, J.L., Hofmann, S.M., Vlassara, H., and Shi, Y.
Diabetes-induced oxidative stress and low-grade inflammation in porcine coronary arteries. Circulation. 108 (4) $472-8$ (2003)

240. Liu, S., Ma, X., Gong, M., Shi, L., Lincoln, T., and Wang, S. Glucose down-regulation of cGMP-dependent protein kinase I expression in vascular smooth muscle cells involves NAD $(\mathrm{P}) \mathrm{H}$ oxidase-derived reactive oxygen species. Free Radic Biol Med. 42 (6) 852-63 (2007)

241. Nishikawa, T., Edelstein, D., Du, X.L., Yamagishi, S., Matsumura, T., Kaneda, Y., Yorek, M.A., Beebe, D., Oates, P.J., Hammes, H.P., Giardino, I., and Brownlee, M. Normalizing mitochondrial superoxide production blocks three pathways of hyperglycaemic damage. Nature. 404 (6779) 787-90 (2000)

242. Hink, U., Li, H., Mollnau, H., Oelze, M., Matheis, E., Hartmann, M., Skatchkov, M., Thaiss, F., Stahl, R.A., Warnholtz, A., Meinertz, T., Griendling, K., Harrison, D.G., Forstermann, U., and Munzel, T. Mechanisms underlying endothelial dysfunction in diabetes mellitus. Circ Res. 88 (2) E14-22 (2001)

243. Ohshiro, Y., Ma, R.C., Yasuda, Y., HiraokaYamamoto, J., Clermont, A.C., Isshiki, K., Yagi, K., Arikawa, E., Kern, T.S., and King, G.L. Reduction of diabetes-induced oxidative stress, fibrotic cytokine expression, and renal dysfunction in protein kinase Cbetanull mice. Diabetes. 55 (11) 3112-20 (2006)

244. Taylor, P.D., McConnell, J., Khan, I.Y., Holemans, K., Lawrence, K.M., Asare-Anane, H., Persaud, S.J., Jones, P.M., Petrie, L., Hanson, M.A., and Poston, L. Impaired glucose homeostasis and mitochondrial abnormalities in offspring of rats fed a fat-rich diet in pregnancy. $\mathrm{Am} \mathrm{J}$ Physiol Regul Integr Comp Physiol. 288 (1) R134-9 (2005)

245. Kwan, J., Wang, H., Munk, S., Xia, L., Goldberg, H.J., and Whiteside, C.I. In high glucose protein kinase Czeta activation is required for mesangial cell generation of reactive oxygen species. Kidney Int. 68 (6) 2526-41 (2005)

246. Yuan, H., Lu, Y., Huang, X., He, Q., Man, Y., Zhou, Y., Wang, S., and Li, J. Suppression of NADPH oxidase 2 substantially restores glucose-induced dysfunction of pancreatic NIT-1 cells. FEBS J. 277 (24) 5061-71 (2010)

247. Aguiari, P., Leo, S., Zavan, B., Vindigni, V., Rimessi, A., Bianchi, K., Franzin, C., Cortivo, R., Rossato, M., Vettor, R., Abatangelo, G., Pozzan, T., Pinton, P., and Rizzuto, R. High glucose induces adipogenic differentiation of muscle-derived stem cells. Proc Natl Acad Sci U S A. 105 (4) 1226-31 (2008)

248. Giacco, F. and Brownlee, M. Oxidative stress and diabetic complications. Circ Res. 107 (9) 1058-70 (2010)

249. Subasinghe, W., Syed, I., and Kowluru, A. Phagocytelike NADPH oxidase promotes cytokine-induced mitochondrial dysfunction in pancreatic beta-cells: 
evidence for regulation by Rac1. Am J Physiol Regul Integr Comp Physiol. 300 (1) R12-20 (2011)

250. San Jose, G., Bidegain, J., Robador, P.A., Diez, J., Fortuno, A., and Zalba, G. Insulin-induced NADPH oxidase activation promotes proliferation and matrix metalloproteinase activation in monocytes/macrophages. Free Radic Biol Med. 46 (8) 1058-67 (2009)

251. Goldstein, B.J., Mahadev, K., Wu, X., Zhu, L., and Motoshima, H. Role of insulin-induced reactive oxygen species in the insulin signaling pathway. Antioxid Redox Signal. 7 (7-8) 1021-31 (2005)

252. Tong, X., Hou, X., Jourd'heuil, D., Weisbrod, R.M., and Cohen, R.A. Upregulation of Nox 4 by TGF $\{$ beta $\} 1$ oxidizes SERCA and inhibits NO in arterial smooth muscle of the prediabetic Zucker rat. Circ Res. 107 (8) 975-83 (2010)

253. Ihm, S.H., Lee, J.O., Kim, S.J., Seung, K.B., SchiniKerth, V.B., Chang, K., and Oak, M.H. Catechin prevents endothelial dysfunction in the prediabetic stage of OLETF rats by reducing vascular NADPH oxidase activity and expression. Atherosclerosis. 206 (1) 47-53 (2009)

254. Wautier, M.P., Chappey, O., Corda, S., Stern, D.M., Schmidt, A.M., and Wautier, J.L. Activation of NADPH oxidase by AGE links oxidant stress to altered gene expression via RAGE. Am J Physiol Endocrinol Metab. 280 (5) E685-94 (2001)

255. Anderson, M.M. and Heinecke, J.W. Production of N (epsilon)- (carboxymethyl)lysine is impaired in mice deficient in NADPH oxidase: a role for phagocyte-derived oxidants in the formation of advanced glycation end products during inflammation. Diabetes. 52 (8) 2137-43 (2003)

256. Zhang, H., Morgan, B., Potter, B.J., Ma, L., Dellsperger, K.C., Ungvari, Z., and Zhang, C. Resveratrol improves left ventricular diastolic relaxation in type 2 diabetes by inhibiting oxidative/nitrative stress: in vivo demonstration with magnetic resonance imaging. $\mathrm{Am} J$ Physiol Heart Circ Physiol. 299(4): p. H985-94.(2010)

Abbreviations: The abbreviations used are: Ang II, angiotensin II; ApoE, Apolipoprotein E; ASK1, apoptosis signal-regulating kinase; bFGF, basic fibroblast growth factor; $\quad \mathrm{BH}_{4}, \quad$ tetrahydrobiopterin; $\quad$ CaMKII, $\mathrm{Ca} 2+/$ calmodulin-dependent protein kinase II; CHOP, $\mathrm{C} / \mathrm{EBP}-$ homologous protein; $\mathrm{CO}$, carbon monoxide; ECM, extracellular matrix; EDHF, endothelium-dependent hyperpolarizing factor; eNOS, endothelial nitric oxide synthase; ER, endoplasmic reticulum; ERK1/2, extracellular signal regulated kinase; ERO-1, ER oxidoreductin 1; ET-1, endothelin-1; $\mathrm{H}_{2} \mathrm{O}_{2}$, hydrogen peroxide; HIF, Hypoxia-inducible factor; HO-1, heme oxygenase; HSP, heat shock protein; IGF-1, insulin-like growth factor-1; IKKalpha -inhibitor of NFkappaB kinasealpha; JNK, c-Jun N-terminal kinase; LPS, lipopolysaccharide; MAPK, mitogen-activated protein kinase; MKP-1, MAPK phosphatase-1; MMP, matrix metalloproteinase; MnSOD, manganese superoxide dismutase; MRTF, myocardin-related transcription factor; NFkappaB, nuclear factor kappa B; NO, nitric oxide; NOX, NADPH oxidase; $\mathrm{O}_{2}{ }^{-}$, superoxide anion; OLETF, Otsuka Long-Evans Tokushima Fatty; PAH, pulmonary arterial hypertension; PASMC, pulmonary artery smooth muscle cells; PDGF, platelet-derived growth factor; PDI, protein disulfide isomerase; PI3K, phosphoinositide-3 kinase; PKC, protein kinase $\mathrm{C}$; PPARgama, peroxisome proliferator-activated receptor-gamma; PTP, tyrosineprotein phosphatase; ROS, reactive oxygen species; SERCA, sarco/endoplasmic reticulum ATPase; SHP2, SH2 domain-containing protein tyrosine phosphatase-2; SRF, serum-response factor; SSH1L, slingshot-1 phosphatase; TASK1, Tandem-pore acid-sensing potassium channel1; TGFbeta, transforming growth factor beta; TLR, toll-like receptors; TNFalpha-tumor necrosis factor alpha; TRAF2, TNF receptor-associated factor 2; UPR, unfolded protein response; VEGF, vascular endothelial growth factor; VSMC, vascular smooth muscle cells.

Key Words: Reactive oxygen species, NADPH oxidases, Nox, Vascular disease, Review

Send correspondence to: Kathy K. Griendling, Emory University, Division of Cardiology, 319 WMB, 1639 Pierce Dr, Atlanta, GA 30322, Tel: 404-727-3364, Fax: 404-7273585, E-mail: kgriend@emory.edu

http://www.bioscience.org/current/vol4S.htm 